\title{
A review on the occurrence of Cochliomyia hominivorax (Diptera: Calliphoridae) in Brazil
}

\author{
Revisão da ocorrência de Cochliomyia hominivorax (Diptera: Calliphoridae) no Brasil \\ Livio Martins Costa-Júnior ${ }^{1 *}$ (D); Daniel Praseres Chaves²; Danilo Rodrigues Barros Brito³; Vitor Augusto Ferreira \\ dos Santos ${ }^{1}$; Henrique Nelson Costa-Júnior ${ }^{1}$; Antonio Thadeu Medeiros Barros ${ }^{4}$ \\ ${ }^{1}$ Laboratório de Controle de Parasitos, Centro de Ciências Biológicas e da Saúde, Universidade Federal do Maranhão - UFMA, \\ São Luís, MA, Brasil \\ ${ }^{2}$ Departamento de Patologia, Centro de Ciências Agrárias, Universidade Federal do Maranháo - UFMA, São Luís, MA, Brasil \\ ${ }^{3}$ Laboratório de Sanidade Animal, Instituto Federal do Maranhão, Campus Maracanã, São Luís, MA, Brasil \\ ${ }^{4}$ Embrapa Gado de Corte, Campo Grande, MS, Brasil
}

Received May 14, 2019

Accepted July 03, 2019

\begin{abstract}
Cochliomyia hominivorax (Coquerel, 1858), the New World screwworm, causes primary myiasis in wild and domestic animals in tropical and subtropical regions of Brazil. Although this species is considered to occur throughout the country, organized information about its recorded distribution has not been available until now. This article aimed to provide a comprehensive review of the historical and current data published on both immature (myiasis) and adult stages of $C$. hominivorax in Brazil. A total of 174 articles were found; of these, 141 articles reported myiasis cases in cattle (146 records), humans (68 records), and other mammalian hosts ( 40 records), and captures of adult flies were reported in 33 articles. C. hominivorax is widespread in Brazil, having been recorded in 208 municipalities in all major biomes of the country.
\end{abstract}

Keywords: Screwworm, primary miyasis, epidemiology, Cochliomyia hominivorax.

\section{Resumo}

Cochliomyia hominivorax (Coquerel, 1858), a mosca-da-bicheira, causa miliase primária em animais silvestres e domésticos em regióes tropicais e subtropicais do Brasil. Embora esta espécie seja considerada de ocorrência em todo o país, informaçóes organizadas sobre sua distribuição com base em registros não estavam disponíveis até o momento. Este artigo teve como objetivo fornecer uma revisão abrangente dos dados históricos e atuais publicados sobre o registro de estágios imaturos (mí́ase) e adultos de C. hominivorax, no Brasil. De 174 artigos encontrados, 141 relataram casos de miíase em bovinos (146 relatos), humanos (68 relatos) e outros mamíferos hospedeiros ( 40 relatos) e capturas de adultos de $C$. hominivorax foram registradas em 33 artigos. C. hominivorax encontra-se amplamente distribuída no Brasil, tendo sido registrada em 208 municípios brasileiros em todos os principais biomas do país.

Palavras-chave: Mosca-da-bicheira, miíase primária, epidemiologia, Cochliomyia hominivorax.

\section{Introduction}

The New World screwworm (NWS) fly, Cochliomyia hominivorax (Coquerel, 1858) (Diptera: Calliphoridae), is a major cause of primary myiasis in animals in tropical and subtropical regions of the Americas (WYSS, 2000). The original distribution of this species extended from the southern United

*Corresponding author: Livio Martins Costa Junior. Laboratório de Controle de Parasitos, Departamento de Patologia, Centro de Ciências Biológicas e da Saúde, Universidade Federal do Maranhão - UFMA, São Luís, Maranhão, Brasil. Av. dos Portugueses, 1966, Cidade Universitária do Bacanga, CEP 65080-805, São Luís, MA, Brasil. e-mail: livio.martins@ufma.br; livioslz@yahoo.com
States to central Argentina, including the Caribbean (HALL \& WALL, 1995). Beginning in 1957, a program based on the sterile insect technique eradicated $C$. hominivorax from North and Central America (WYSS, 2000). Currently, a biosecurity facility for screwworm mass rearing, sterilization, and dispersal is maintained in Panama for preventing reintroduction from Colombia (CONCHA et al., 2016). The current distribution of this species comprises the Caribbean and South America, except Chile (FRESIA et al., 2011).

Myiasis is a parasitic infestation of live vertebrate animals by dipterous larvae (ACHA \& SZYFRES, 2003). Although 
several dipteran species may cause myiasis (ZUMPT, 1965; HALL \& WALL, 1995; GUIMARÃES \& PAPAVERO, 1999), $C$. hominivorax is the main species associated with primary myiasis in Brazil (ZUMPT, 1965).

In Brazil, cattle myiasis is more prevalent in newborn calves and is eventually associated with tick infestations (YARZON, 2005; BARROS et al., 2010a; RECK et al., 2014). Aggravated by favorable environments, infrastructure problems and management difficulties, myiasis stands out among the main causes of calf mortality in some Brazilian regions (BARROS et al., 2010b; GRISI et al., 2014).

Although $C$. hominivorax is widely spread throughout the country, information on the distribution and epidemiology of this species in Brazil is scattered, and little information is available about its geographic distribution as well as the prevalence of its myiasis in different host species. A comprehensive study on screwworm distribution in Brazil was performed some decades ago by Horn \& Antônio (1983) when a questionnaire was distributed all over the country by the Serviço Brasileiro de Defesa Sanitária Animal; with a return rate of approximately $75 \%$, the occurrence of myiasis was recorded in $96.2 \%$ of the municipalities from all Brazilian states. In that survey, the highest myiasis prevalence was observed in the Northeast states; in 495 municipalities, screwworm myiasis was the most prevalent cattle ectoparasitosis (HORN \& ANTÔNIO, 1983).

In this sense, the present article is a comprehensive compendium of the historical and current data published about the occurrence of $C$. hominivorax and its myiasis in Brazil. Aspects related to the etiology, distribution, and host occurrence of cutaneous myiasis, mainly due to $C$. hominivorax, are presented to update the overview of this important parasite.

\section{Review procedures}

The present review comprised a comprehensive search of technical and scientific publications using searching tools and databases, such as PubMed, Scielo and Google Scholar, available on the internet. Searching was conducted until December 2017 using several combinations of screwworm-related terms (Calliphoridae, Cochliomyia, myiasis, screwworm) as well as related hosts (cattle, horse, dog, sheep, human) and "Brazil". Articles about adult trapping without the species ( $C$. hominivorax) identification were not considered.

This review included not only new and old information available on the internet but also published articles not available online. Information regarding the occurrence of myiasis in wildlife is very scarce in the Brazilian literature; thus, additional information was provided by some field professionals working in that area.

This paper was mostly based on myiasis records from both case reports and field studies, depending on the host species. Complementary information from adult records, mostly from trapping studies, was also included. Eventually, the number of records was greater than the number of articles since some articles had multiple records.

\section{General results}

The present review covered 227 articles published over the last 142 years (1875 - 2017) reporting myiasis (by different species) and screwworm adult trapping in Brazil. Of these, 174 articles recorded $C$. hominivorax, with $81.1 \%$ (141 articles) reports on myiasis and $18.9 \%$ (33 articles) records of adult trapping.

From 1875 to 1999 , only 24 articles (14.2\%) reported C. hominivorax in Brazil (Figure 1). The number of such articles increased considerably, with 49 (29.0\%) reports from 2000 to 2008, and peaked from 2009 to 2017, with 96 (56.8\%) published articles (Figure 1). It is worth mentioning that until 1999, only a few publications had reported the occurrence of both human myiasis $(n=2)$ and adult trapping $(n=3)$; however, such reports increased considerably to 34 and 25 articles, respectively, from 2009 to 2017 . In addition to those 168 articles, six other articles with no identified hosts were excluded from the analysis.

The occurrence of $C$. hominivorax has been recorded by technical and/or scientific publications in 208 municipalities from 26 states of Brazil. No published records of $C$. hominivorax were found for the state of Alagoas (Northeast region); however, myiasis by $C$. hominivorax and/or adult catches has been recorded in neighboring states. Anecdotal information from field veterinarians confirms its distribution in all Brazilian states. Without confirming species identification, Horn \& Antônio (1983) had previously reported the occurrence of cattle myiasis in all states of the country.

Most published records (41.8\%) of both screwworm myiasis (on all hosts) and adult catches were from the Southeast region of the country (Table 1); however, this finding most likely resulted from a much greater number of studies carried out in that region during the years rather than a higher abundance of this fly in the region. Indeed, the number of published reports ultimately reflects the number of studies conducted in each particular region and does not necessarily represent (or should be interpreted as an indicator of) screwworm abundance or importance.

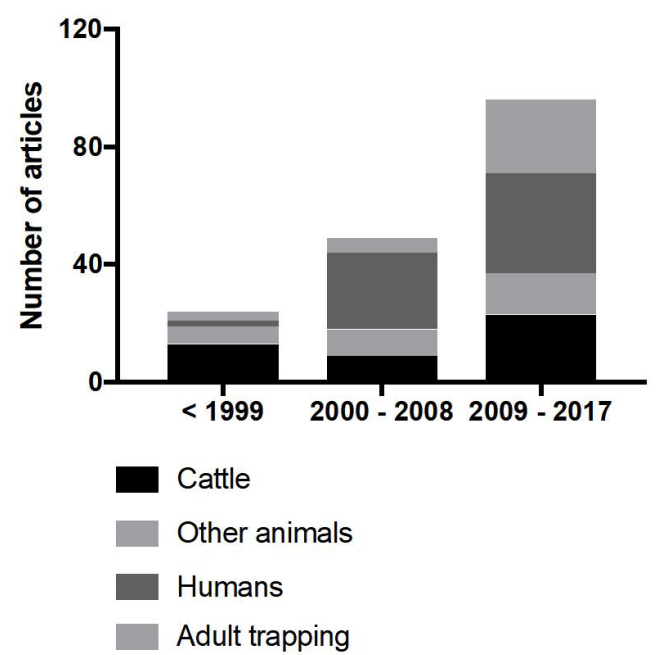

Figure 1. Temporal distribution of scientific publications $(n=168)$ recording Cochliomyia hominivorax immatures (myiasis) and adults' in Brazil from 1875 to 2017. 


\section{Cattle Myiasis}

The specific occurrence of cattle myiasis was recorded in 127 municipalities distributed throughout all five regions of the country (Figure 2A, Table 2). Cochliomyia hominivorax was the most important species associated with cattle myiasis in Brazil and was responsible for all cases where the etiologic agent was identified (Table 3). The distribution of cattle myiasis in Brazil is certainly broader than it is presented here (Table 2 and Figure 2A), as suggested by Horn \& Antônio (1983). However, a more complete distribution of this pest depends on further studies, mainly in regions where information is scarce or simply does not exist. The absence of species confirmation, as observed in several reports, also limits epidemiological studies.

The highest number of records of myiasis in cattle (87.6\%) was recorded in the Southeast (34.2\%), Midwest (30.8\%) and South (22.6\%) regions (Table 1 ). This distribution is highly influenced by two major factors: 1) a greater number of scientific articles in the

Table 1. Frequency distribution (\%) of Cochliomyia hominivorax myiasis and adult records from articles published from 1875 to 2017 $(\mathrm{n}=174)$ in Brazil.

\begin{tabular}{|c|c|c|c|c|c|}
\hline \multirow{2}{*}{ Region } & \multicolumn{3}{|c|}{ Myiasis records* } & \multirow{2}{*}{ Trapping records } & \multirow{2}{*}{ Total } \\
\hline & Humans & Cattle & Other hosts & & \\
\hline North & $5.9(4)$ & $6.8(10)$ & $2.5(1)$ & $10.5(4)$ & $6.5(19)$ \\
\hline Northeast & $13.2(9)$ & $5.5(8)$ & $27.5(11)$ & $21.1(8)$ & $12.3(36)$ \\
\hline Midwest & $1.5(1)$ & $30.8(45)$ & $15.0(6)$ & $26.3(10)$ & $21.2(62)$ \\
\hline Southeast & $63.2(43)$ & $34.2(50)$ & $45.0(18)$ & $28.9(11)$ & $41.8(122)$ \\
\hline South & $16.2(11)$ & $22.6(33)$ & $10.0(4)$ & $13.2(5)$ & $18.2(53)$ \\
\hline Total of Records & 68 & 146 & 40 & 38 & 292 \\
\hline
\end{tabular}

${ }^{*}$ Records without host $(\mathrm{n}=32)$ or state $(\mathrm{n}=1)$ identification were not considered in the present analysis. The frequency is followed by number of records in this table.
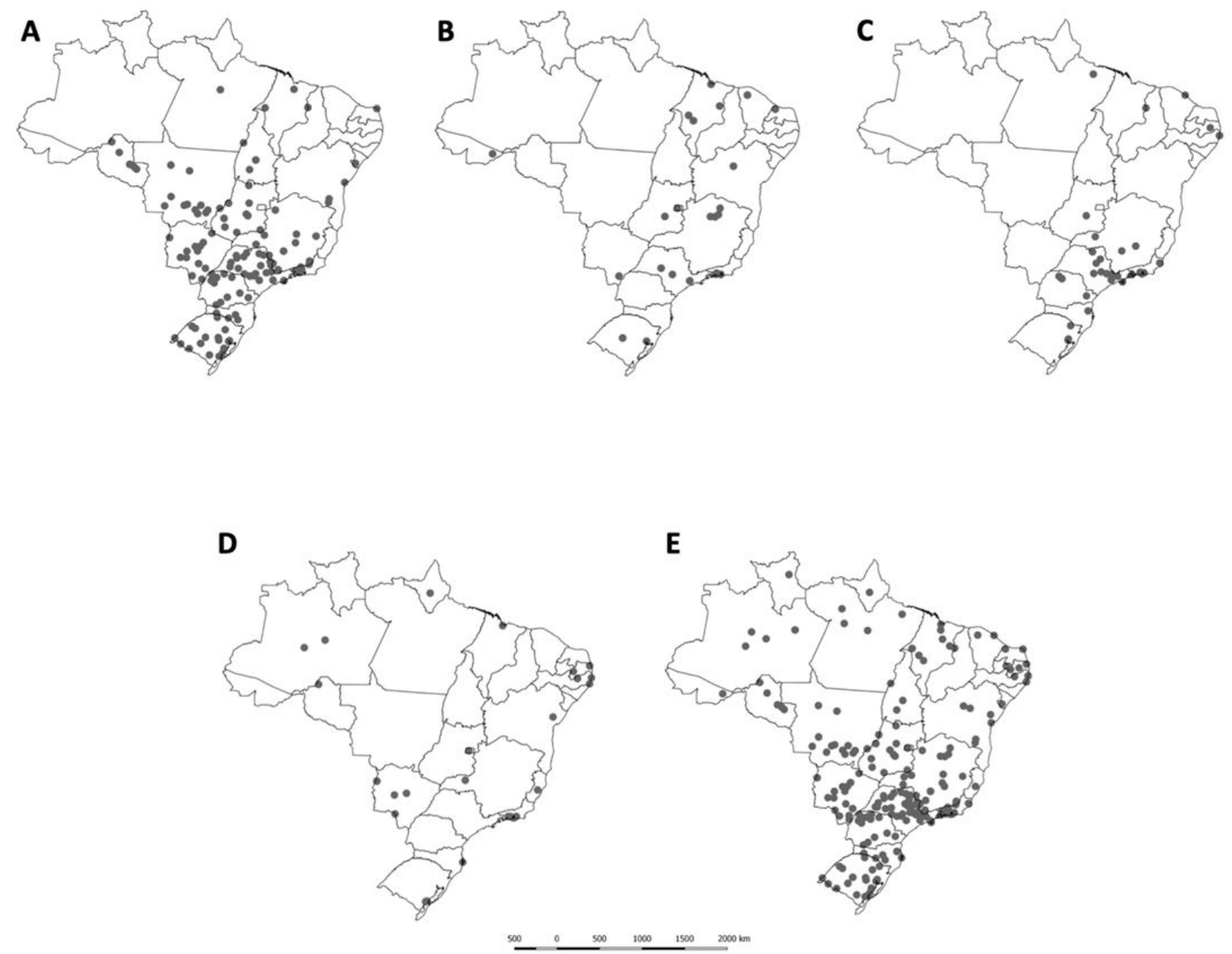

Figure 2. Distribution of Cochliomyia hominivorax records in Brazil: cattle myiasis (A); pets, other livestock and wildlife myiasis (B); human myiasis (C); adult trapping (D); and overall species distribution (E). Records without host were considered to overall species distribution map. 
Table 2. Geographic occurrence of Cochliomyia hominivorax according to published records of myiasis occurrence and adult catches in Brazil.

\begin{tabular}{|c|c|}
\hline State & Municipalities \\
\hline $\mathrm{AC}$ & Rio Branco \\
\hline AM & Coari $^{1}$, Manaus, Porto Urucu ${ }^{1}$, Tefé \\
\hline $\mathrm{AP}$ & Serra do Navio ${ }^{1}$ \\
\hline BA & $\begin{array}{l}\text { Barra do Choça, Feira de Santana }{ }^{1} \text {, Irecê, Itambé, Jaguaripe, } \\
\text { Morro do Chapéu }\end{array}$ \\
\hline $\mathrm{CE}$ & Fortaleza, Sobral \\
\hline DF & Brasília $^{2}$ \\
\hline
\end{tabular}

ES Santa Teresa ${ }^{1}$

GO Caiapônia, Catalão, Goianésia, Goiânia, Goianira, Itaberaí, Jataí, Jussara, Porangatu, Quirinópolis, Rio Verde

MA

MG

Caxias, Coroatá, Formosa da Serra Negra, Grajaú, Santa Rita, São Francisco do Brejão, São Luís, Sítio Novo

Além Paraíba, Alfenas, Belo Horizonte, Capim Branco, Coração de Jesus, Estiva, Formiga, Francisco Sá, Governador Valadares, Janaúba, Leopoldina, Monte Carmelo, Montes Claro, Poços de Caldas, Presidente Juscelino, Santa Vitória, São Sebastião do Paraíso, Uberaba, Uberlândia², União de Minas, Veríssimo

MS Amambaí, Aquidauana², Bandeirante, Bonito, Camapuã, Campo Grande $^{2}$, Corumbá2, Costa Rica, Itaquiraí, Ivinhema, Jardim, Naviraí, Nioaque, Ponta Porã ${ }^{1}$, Rio Brilhante, Rochedo, Três Lagoas

MT Barra das Garças, Chapada dos Guimarães, Cocalinhos, Cuiabá, Guiratinga, Juara, Jucimeira, Primavera do Leste, Rondonópolis, São José dos Quatro Marcos, Sinop, Tangará da Serra, Tesouro

PA Alenquer, Altamira, Belém, Santa Maria das Barreiras, Santarém

PB Campina Grande, Patos, Rio Tinto ${ }^{1}$, São José dos Cordeiros ${ }^{1}$

PE Brejo da Madre de Deus ${ }^{1}$, Recife ${ }^{2}$, Tamandaré
Reference

Fresia et al., 2014; Mastrangelo et al., 2014; Reis et al., 2016

Lessinger \& Azeredo-Espin, 2000; Litjens et al., 2001; Azeredo-Espin \& Lessinger, 2006; Esposito et al., 2010; Sousa et al., 2010; Fresia et al., 2014; Mastrangelo et al., 2014

Couri et al., 2000

Azeredo-Espin, 1987; Caproni et al., 1998; Junqueira et al., 2002; Azeredo-Espin \& Lessinger, 2006; Almeida et al., 2008; Fresia, 2011; Bergamo et al., 2015; Santos \& Andena, 2017

Costa \& Vieira, 1984; Jorge et al., 2016

Cansi et al., 2011; Cansi \& Bonorino, 2011; Cansi \& Demo, 2011; Harterreiten-Souza \& Pujol-Luz, 2012; Name et al., 2012; Kosmann, 2013

Barbosa et al., 2014

Lustosa et al., 1983; Azeredo-Espin, 1987; Caproni et al., 1998; Garcia-Zapata et al., 2005; Fernandes et al., 2009; Lyra et al., 2009, 2010; Carvalho et al., 2009; Carvalho et al., 2010; Fresia et al., 2011; 2013; 2014; Silva et al., 2011; Cardoso et al., 2014, 2016; Lopes et al., 2014; Bergamo et al., 2015;

Teixeira et al., 2016

Caproni et al., 1998; Brito et al., 2005; Reis et al., 2008; Figueiredo et al., 2010; Fresia et al., 2014; Mastrangelo et al., 2014; Pereira de Sousa et al., 2015, 2016

Azeredo-Espin, 1987; Caproni et al., 1998; Lessinger \& Azeredo-Espin, 2000; Litjens et al., 2001; Duarte et al., 2012; Junqueira et al., 2002; Gomez et al., 2003; Lima et al., 2004; Abdo et al., 2006; Oliveira et al., 2008; Silva, 2008; Amos, 2009; Lyra et al., 2009, 2010; Fresia et al., 2011; 2013; 2014; Silva et al., 2011; Ribeiro et al., 2012b; Lopes et al., 2013; Teixeira et al., 2013; Bergamo et al., 2015; Silva et al., 2015; Faria et al., 2018

Bianchin et al., 1991, 1992; Caproni et al., 1998; Gomes et al., 1998; Koller et al., 2002, 2011; Oliveira et al., 2006; Pires, 2008; Lyra et al., 2009; Barros et al., 2010a,b; Corrêa et al., 2010; Xavier, 2010; Fresia et al., 2011; 2013; 2014; Taira et al., 2011; Luiz et al., 2012; Bergamo et al., 2015; Souza et al., 2016; Kosmann et al., 2017; Salinas \& Lima, 2017

Rivera \& Aycardi, 1985; Azeredo-Espin, 1987; Caproni et al., 1998; Fresia et al., 2011; 2013; 2014

Caproni et al., 1998; Seppanen et al., 2004; Saraiva et al., 2006; Gomes de Araújo et al., 2009; Lyra et al., 2009; Silva et al., 2011; Fresia et al., 2011; 2013; 2014; Ribeiro et al., 2012a; Mastrangelo et al., 2014

Fresia et al., 2013; Alves et al., 2014; Cavalcante et al., 2015; Holanda et al., 2015

Melo et al., 2003; Nascimento et al., 2005; Fresia, 2011; Laureano-Filho et al., 2011; Figueirêdo et al., 2015; Oliveira et al., 2016; Arruda et al., 2017 
Table 2. Continued...

\begin{tabular}{|c|c|}
\hline State & Municipalities \\
\hline PI & Teresina \\
\hline PR & $\begin{array}{l}\text { Carambeí, Colombo, Guarapuava, Jataizinho, Jundiaí Sul, } \\
\text { Loanda, Mangueirinha, Maria Helena, Maringá, Nossa Senhora } \\
\text { das Graças, Nova Esperança, Pato Branco, Paraíso do Norte, } \\
\text { Sarandi, Tuneiras Oeste }\end{array}$ \\
\hline RJ & 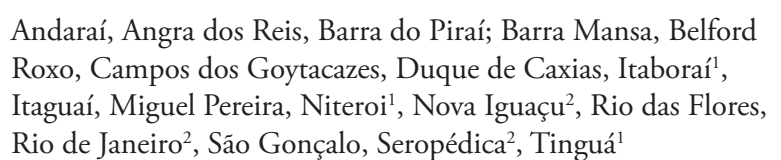 \\
\hline
\end{tabular}

RN Mossoró, Touros

RO Ariquemes, Cacoal, P. Bueno, Porto Velho², Presidente Médici

Caproni et al., 1998; Silva et al., 2005a, b; Lopes-Costa et al., 2008; Fresia et al., 2014; Mastrangelo et al., 2014

Caproni et al., 1998; Chicarelli et al., 2002; Gealh et al., 2009; Kotze et al., 2009; Lyra et al., 2009, 2010; Fresia et al., 2011; 2013; 2014; Silva et al., 2011; Costa et al., 2012; Bergamo et al., 2015

Oliveira, 1980; D’Almeida, 1983; Muniz et al., 1995; Sanavria \& Prata, 1996; Taylor et al., 1996; Caproni et al., 1998; Figueiredo et al., 2002, 2006; Passos et al., 2002; Cramer-Ribeiro et al., 2002a,b, 2003; Oliveira et al., 2006; D’Almeida \& Fraga, 2007; Marquez et al., 2007; Mendes-de-Almeida et al., 2007; Deleito \& Moya-Borja, 2008; Ferraz et al., 2008, 2010a,b; 2011; Rodrigues-Guimarães et al., 2008; Pires, 2008; Batista-da-Silva et al., 2009; Correia et al., 2010; Ferraz et al., 2010a, b; Souza CP et al., 2010a; Souza JR et al., 2010b; Batista-da-Silva et al., 2011a, b, c, 2012; Batista-da-Silva, 2015; Braga et al., 2011; Fresia, 2011; Gonçalves et al., 2011; Marotta et al., 2011; Marotta et al., 2011; Lucares et al., 2013; Oliveira-Costa et al., 2013; Valviesse et al., 2014; Azevedo et al., 2015; Gadelha et al., 2015; Rodrigues et al., 2017; Oliveira et al., 2018

Bezerra et al., 2010; Fresia et al., 2011; 2013; 2014; Bergamo et al., 2015

Caproni et al., 1998; Serbino et al., 2010

Fresia et al., 2014; Mastrangelo et al., 2014

Souza, 1939; Azeredo-Espin, 1987; Ribeiro et al., 1993; Taylor et al., 1996; Ribeiro et al., 1997; Caproni et al., 1998; Junqueira et al., 2002; Vianna et al., 2004; Spagnol et al., 2006; Manfrim et al., 2007; Rossi-Schneider et al., 2007; Fighera, 2008.; Lyra et al., 2009, 2010; Barrientos Pontes et al., 2009; Souza et al., 2009; Carmo et al., 2011; Fresia et al., 2011; 2013; 2014; Silva et al., 2011; Martins et al., 2012; Schmidt et al., 2012; Azevedo \& Krüger, 2013; Reck et al., 2014; Bergamo et al., 2015

SC Blumenau, Celso Ramos, Chapecó, Curitibanos, Florianópolis ${ }^{1}$; Lages

Caproni et al., 1998; Martins-Junior et al., 2010; Paim, 2010; Bernaschina, 2016

Caproni et al., 1998

Vaz \& Carvalho, 1938; Rocha \& Vaz, 1950; Abdallah et al., 1970; Azeredo-Espin, 1987; Silva et al., 1991; Amarante et al., 1992; Vargas \& Azeredo-Espin, 1995; Caproni et al., 1998; Rocha et al., 1999; Gennari et al., 2000; Lessinger et al., 2000; Litjens et al., 2001; Ribeiro et al., 2001; Junqueira et al., 2002; Itapetininga, Itatinga, José Bonifácio, Martinópolis, Morro Agudo, Nova Odessa, Oscar Bressane, Paulínia, Piracicaba, Pirassununga, Poconé, Presidente Prudente, Ribeirão Preto, Santa Cruz do Rio Pardo, Santo Antônio do Aracanguá, São Carlos, São João da Boa Vista, São José do Rio Pardo, São José dos Campos, São Paulo, Valinhos Martinez et al., 2003; Rodriguez et al., 2003; Shinohara et al., 2004; Tarso et al., 2004; Azeredo-Espin \& Lessinger, 2006; Pasternak et al., 2007; Pena, 2007; Takahagi et al., 2007; Barbosa et al., 2008; Rossi et al., 2009; Lima-Júnior et al., 2010; Lyra et al., 2010; Loureiro et al., 2010; Ribeiro et al., 2010; Antunes et al., 2011; Fresia et al., 2011; 2013; 2014; Vale et al., 2011; Ribeiro et al., 2012a; Thyssen et al., 2012; Lopes et al., 2013, 2017; Sellera et al., 2014; Baptista, 2015; NovoNeto et al., 2015; Giglioti et al., 2016; Ribeiro \& Monnazzi, 2016; Calderon et al., 2017 
Table 3. Frequency of published records of myiasis by dipteran species and hosts in Brazil. ${ }^{1}$

\begin{tabular}{|c|c|c|c|c|c|}
\hline Diptera species & $\begin{array}{c}\text { Cattle } \\
(\mathrm{n}=150) \\
\end{array}$ & $\begin{array}{c}\text { Humans } \\
(\mathrm{n}=108)^{\mathrm{a}}\end{array}$ & $\begin{array}{l}\text { Small ruminants } \\
\quad(\mathrm{n}=30)\end{array}$ & $\begin{array}{l}\text { Others domestic } \\
\text { animals }(n=28)\end{array}$ & $\begin{array}{l}\text { Wild mammals } \\
\quad(n=5)\end{array}$ \\
\hline \multicolumn{6}{|l|}{ Calliphoridae } \\
\hline Cochliomyia hominivorax & $97.3(146)$ & $63.9(69)$ & $56.7(17)$ & $64.3(18)$ & $80.0(4)$ \\
\hline Cochliomyia macellaria & - & $2.8(3)$ & - & - & - \\
\hline Chrysomya albiceps & - & $2.8(3)$ & $3.3(1)$ & - & - \\
\hline Chrysomya megacephala & - & $1.8(2)$ & - & - & - \\
\hline Lucilia cuprina & - & $2.8(3)$ & - & - & - \\
\hline Lucilia eximia ${ }^{2}$ & - & - & - & $14.3(4)$ & $20.0(1)$ \\
\hline \multicolumn{6}{|l|}{ Syrphidae } \\
\hline Eristalis tenax & - & $2.8(3)$ & - & - & - \\
\hline Ornidia obesa & - & $0.9(1)$ & - & - & - \\
\hline \multicolumn{6}{|l|}{ Muscidae } \\
\hline Musca domestica & - & $0.9(1)$ & - & $3.6(1)$ & - \\
\hline Sarcophagidae & - & $5.6(6)^{3}$ & - & - & - \\
\hline Not identified & $2.7(4)$ & $15.7(17)$ & $40.0(12)$ & $17.9(5)$ & - \\
\hline
\end{tabular}

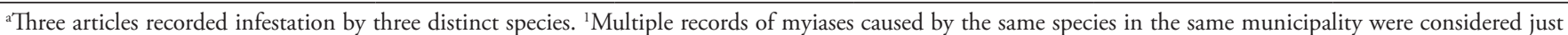
once. ${ }^{2}$ Phaenicia eximia was considered a synom of Lucilia eximia. ${ }^{3}$ Includes Sarcophaga pyophila, Sarcophaga ruficornis, Sarcodexia lambens and Sarcophaga sp.

area of agrarian sciences from researchers in the Southeast, South and Midwest, totaling 86\% (1992-1994) and 79\% (2007-2009) of Brazilian scientific production (SIDONE et al., 2016), and 2) a larger cattle herd in these regions, representing $66 \%$ and $78 \%$ of the national bovine population in 1980 and 2010, respectively (IBGE, 2018).

Forty-five articles provided 146 reports of cattle myiasis; of these, 20 were about molecular or biochemical aspects, 16 were tests of drug or plant extract efficacy, and the others were case reports (four articles), epidemiology (three articles), general survey of ectoparasites (one article) and control using the sterile insect technique (one article).

\section{Myiasis on other animal hosts}

Several domestic animals have been reported as hosts to dipteran larvae in Brazil (Table 3). Most records were from myiasis in dogs $(n=14)$, followed by cats $(n=8)$, horses $(n=2)$, and buffalo, donkey, rabbits and pigs $(\mathrm{n}=1$, each). In general, the clinical resolution of myiasis in domestic animals will depend on the location and extent of injury, intensity of infestation, speed of diagnosis and effective treatment, and the dipteran species involved (CORREIA et al., 2010).

Cochliomyia hominivorax was responsible for $64.3 \%$ of the myiasis reported in domesticated animals (other than bovines), which included dog, cat, goat, sheep, horse, donkey, buffalo and pig, in various regions of the country.

Myiasis in pets due to $C$. hominivorax has been reported in dogs and cats. Nine articles reported the occurrence of myiasis in dogs in the states of Rio Grande do Sul (SPAGNOL et al., 2006; FIGHERA, 2008; SOUZA et al., 2009), Rio de Janeiro (CRAMERRIBEIRO et al., 2003; CORREIA et al., 2010), Federal District (CANSI \& DEMO, 2011; NAME et al., 2012), São Paulo (PENA, 2007) and Goiás (LUSTOSA et al., 1983). Myiasis in cats has been reported only in Rio de Janeiro (MENDES-DE-ALMEIDA et al.,
2007; SOUZA CP et al., 2010a; MAROTTA et al., 2011) and the Federal District (CANSI \& DEMO, 2011). The occurrence of myiasis in pets is certainly underestimated in all states.

Brazil has more than eight million goats and thirteen million sheep, concentrated in the Northeast and South regions (IBGE, 2018). Thirty records of myiasis (by distinct species) in small ruminants, including 19 in sheep and 11 in goats (Table 3), from 11 states, were found in 13 articles. Approximately 56.6\% of the records $(n=17)$ were from the Northeast region (Table 2), although most of this region is semiarid and has a smaller number of myiasis cases.

Most myiasis reports in small ruminants in Brazil were caused by $C$. hominivorax ( $\mathrm{n}=17$ records); however, in $40 \%$ of the records, the species was not identified (Table 3). Small ruminants infested by myiasis could be mutilated because of the rapid development of myiasis, often in less than 24 hours. The articles recording myiasis by $C$. hominivorax in small ruminants were case reports (SCHMIDT et al., 2012; SELLERA et al., 2014; REIS et al., 2016), surveys of ectoparasites (COSTA \& VIEIRA, 1984; BRITO et al., 2005; BEZERRA et al., 2010), epidemiology studies (AMARANTE et al., 1992; DUARTE et al., 2012) and ectoparasiticide efficacy trials (SANAVRIA \& PRATA, 1996).

Although $C$. hominivorax was responsible for the majority $(64.3 \%)$ of the myiasis reported in domesticated animals (other than bovines), Lucilia eximia (Wiedemann, 1981) has been found in $14.3 \%$ of cases (Table 3 ), including dogs, cats, and rabbits (MADEIRA et al., 1989; AZEREDO-ESPIN \& MADEIRA, 1996; MORETTI \& THYSSEN, 2006; CANSI \& DEMO, 2011).

Relatively little information is available regarding the occurrence of myiasis in wild animals in Brazil. In nature, primary myiasis caused by $C$. hominivorax has been reported only in the maned wolf (Chrysocyon brachyurus Illiger, 1815) in Brasilia (CANSI et al., 2011) and opossum (Didelphis marsupialis Linnaeus, 1758) in Caxias, Maranhão state (REIS et al., 2008). In captive animals, myiasis by $C$. hominivorax has been recorded in the hippopotamus 
(Hippopotamus amphibious Linnaeus, 1758) and the lesser grison (Galictis cuja Molina, 1782) in São Paulo and São Luís (ROSSI et al., 2009; FIGUEIREDO et al., 2010). Myiasis by other species has also been reported in a captive white-eared opossum (Didelphis albiventris Lund, 1840) from Brasilia caused by L. eximia (CANSI \& BONORINO, 2011). Except for D. albiventris, all myiasis reported in wild mammals in Brazil was caused by $C$. hominivorax.

The scarcity of information on myiasis in wild mammals should not be considered as the absence of this problem in wildlife, but to the lack of specific studies as well as a better use of field opportunities during ecological studies.

Additional unpublished or anecdotal observations of myiasis in wildlife also included puma (Puma concolor Linnaeus, 1771) in 2013 from São Paulo and Minas Gerais (Fernanda C. Azevedo e Frederico G. Lemos, personal communication), red-footed tortoise (Geochelone carbonaria Spix, 1824) in 2011 from Uberaba, Minas Gerais state and maned wolf in the mountain region of Rio de Janeiro in. In all those cases, the actual species causing myiasis is unknown.

Although the parasitism of birds by $C$. hominivorax larvae is quite uncommon, such a situation has been found in a captive ostrich (Struthio camelus Linnaeus, 1758) in the semiarid region of the state of Bahia (ALMEIDA et al., 2008). Indeed, myiasis in small wild birds of several species is commonly caused by Philornis larvae (LUZ et al., 2008, 2010, 2011; FRANZ \& COURI, 2008).

Myiasis due to the primary screwworm has not been reported in anurans and reptiles in Brazil. However, Sarcophagidae larvae have been found in tree frogs (Hypsiboas beckeri Caramaschi and Cruz, 2004 and Aplastodiscus arildae Cruz and Peixoto, 1987) (EIZEMBERG et al., 2008; MELLO-PATIU \& LUNA-DIAS, 2010) and in the introduced American bullfrog (Rana catesbeiana Shaw, 1802) (SOUZA et al., 1989). The single record of myiasis in reptiles in Brazil was from the South American rattlesnake (Crotalus durissus Linnaeus, 1758) caused by Phoridae larvae (SILVA et al., 1999).

\section{Human Myiasis}

Zoonotic infestations by dipteran larvae are of great public health importance, and people with inadequate hygienic habits are the most likely to have cutaneous lesions and/or systemic diseases, thus becoming more susceptible to such infestations (MARTINEZ et al., 2003). Clinical manifestations of myiases depend on the dipteran species involved and the organ or tissue affected (PIERCE, 1981), and the prognosis is directly related to the duration and location of the injury and the health conditions of the patient (NASCIMENTO et al., 2005).

One of the first reports of myiasis in Brazil was by Brandão $\&$ Menezes (1875), who included more than 30 cases in humans, mainly in nasal cavities; unfortunately, the species was not identified. Since then, some cases of human mortality due to myiasis have been reported in Brazil (BLEYER, 1905; SOUZA, 1939; CARVALHO et al., 2008; HOLANDA et al., 2015).

Human myiasis has been recorded in 44 municipalities from 15 states in all regions of Brazil (Figure 2C, Table 1, Table 2). Most reports $(59.7 \%)$ refer to the occurrence of myiasis in the head and neck; however, there are also several cases of genital myiasis. The vast majority $(\mathrm{n}=51)$ of the articles about human myiasis caused by C. hominivorax are limited to simple case descriptions, and only a few articles show a therapeutic and/or epidemiological approach. Most records of human myiasis in Brazil are from the Southeast region (63.2\%) (Table 1), particularly from Rio de Janeiro and São Paulo, which represent $29.4 \%$ and $26.4 \%$, respectively, of all records of human myiasis from Brazil.

Although several dipteran species have been identified in human myiasis, $C$. hominivorax is by far the most important species, present in $63.9 \%$ of the cases. Other etiological agents of human myiasis included sarcophagids, found in 5.6\% of the particles, as well as Cochliomyia macellaria (Fabricius, 1775), Chrysomya albiceps (Wiedemann, 1819), Eristalis tenax (Linnaeus, 1758 ) and Lucilia cuprina (Meigen, 1826) identified in $2.8 \%$ of the cases (Table 3).

\section{Adult records}

Although myiasis studies themselves have provided robust information on screwworm distribution in Brazil, the lack of such studies in some states leaves a gap in the occurrence of this species in those regions. Actually, the absence of specific information for a particular region does not necessarily imply that either livestock or myiasis are not important at the region; instead, it most probably reflects the absence of studies on this particular subject in that state.

Additional information obtained from screwworm adult captures contributed to providing a more complete distribution of $C$. hominivorax in the country (Figure 2D, Table 2). Adults of $C$. hominivorax have been caught in several sites, mainly by traps baited with carcasses (ALVES et al., 2014; FARIA et al., 2018), rotting viscera or other decaying material (KOLLER et al., 2002, 2011; SOUSA et al., 2010; GONÇALVES et al., 2011; GADELHA et al., 2015; PEREIRA DE SOUSA et al., 2015, 2016; OLIVEIRA et al., 2016). Although decaying baits are not the best attractant to a fly species causing primary myiasis, this relatively inexpensive and simple choice has provided useful information on the distribution of $C$. hominivorax in Brazil (Figure 2E). In fact, of the 33 articles recording catches of $C$. hominivorax adults, 31 were about general Calliphoridae ecology or epidemiology.

In general, of the 325 records with information on $C$. hominivorax distribution in Brazil, only 38 (11.7\%) came from trapping studies. Although relatively little information was provided by such studies, C. hominivorax adults were caught in 14 states (Table 1), expanding their distribution to two more states and nine municipalities in which no information on myiasis was previously available.

Those situations reinforce that, despite the considerable number of studies on myiasis, the geographic distribution of the species in the country is not limited to the regions where such studies have been conducted.

\section{Conclusions}

Cochliomyia hominivorax is the most important species causing primary myiasis in livestock, pets and man in Brazil. Geographic distribution of the screwworm in Brazil based on historical and 
recently published data confirms its distribution throughout the country. Although most records were from cattle studies, the occurrence of primary myiasis has been quite reported in pets as well as in humans, evidence of the social and economic importance of the screwworm in both human and animal health.

\section{Acknowledgements}

The authors wish to thank the CNPq (Brazilian National Council for Scientific and Technological Development) for awarding a scholarship to V.A.F. Santos and a fellowship to L.M. Costa-Júnior. We also thank FINEP (Funding Authority for Studies and Projects) and FAPEMA (Maranhão State Research Foundation) for supporting the IECT (Science and Technology Institute of Maranhão) Biotechnology.

\section{References}

Abdallah SI, Rocha UF, Serra OP, Oba MS, Serra RG. Primary myiasis in buffaloes--Bufalos bubais L., 1758--of the state of São Paulo, Brazil, by Cochliomyia hominivorax (Coquerel, 1858), Diptera Calliphoridae. Rev Farm Bioquim Univ Sao Paulo 1970; 8(1): 135-138. PMid:5527072.

Abdo EN, Sette-Dias AC, Comunian CR, Dutra CE, Aguiar EG. Oral myiasis: a case report. Med Oral Patol Oral Cir Bucal 2006; 11(2): 130131. PMid:16505789.

Acha PN, Szyfres B. Zoonosis y Enfermidades Transmissibles Comunes al Hombre y a los animals. Volumen II, Clamidiosis, rickettsiosis y virosis. 3. ed. Washington: Pan American Health Organization; 2003.

Almeida MA, Duarte LF, Rocha JS, Silva MS, Guimarães JE, Ayres MC. Ocorrência de ectoparasitos em avestruzes (Struthio camelus) criados no semi-árido Baiano. Rev Bras Parasitol Vet 2008; 17(3): 155-157. http:// dx.doi.org/10.1590/S1984-29612008000300007. PMid:19245762.

Alves AC, Santos WE, Farias RC, Creão-Duarte AJ. Blowflies (Diptera, Calliphoridae) associated with pig carcasses in a Caatinga area, Northeastern Brazil. Neotrop Entomol 2014; 43(2): 122-126. http://dx.doi.org/10.1007/ s13744-013-0195-4. PMid:27193518.

Amarante AFT, Barbosa MA, Oliveira-Sequeira TC, Fernandes S. Epidemiology of sheep myiases in São Paulo state, Brazil. Trop Anim Health Prod 1992; 24(1):36-39. http://dx.doi.org/10.1007/BF02357234. PMid:1306916.

Amos CAA. Atividade terapêutica do spinosad contra larvas de Cochliomyia hominivorax (L1, L2 E L3) em bovinos infestados natural e artificialmente [dissertação]. Jaboticabal: Universidade Estadual Paulista; 2009.

Antunes AA, Santos TS, Avelar RL, Martins EC No, Macedo Neres B, Laureano JR Fo. Oral and maxillofacial myiasis: a case series and literature review. Oral Surg Oral Med Oral Pathol Oral Radiol Endod 2011; 112(6): e81-e85. http://dx.doi.org/10.1016/j.tripleo.2011.05.026. PMid:21872507.

Arruda JAA, Oliveira Silva LV, Silva PUJ, Figueiredo EL, Callou G, Mesquita RA, et al. Head and neck myiasis: a case series and review of the literature. Oral Surg Oral Med Oral Pathol Oral Radiol 2017; 124(5): e249-e256. http://dx.doi.org/10.1016/j.oooo.2017.06.120. PMid:28822697.

Azeredo-Espin AM, Lessinger AC. Genetic approaches for studying myiasis-causing flies: molecular markers and mitochondrial genomics.
Genetica 2006; 126(1-2): 111-131. http://dx.doi.org/10.1007/s10709005-1439-y. PMid:16502089.

Azeredo-Espin AM, Madeira NG. Primary myiasis in dog caused by Phaenicia eximia (Diptera: Calliphoridae) and preliminary mitochondrial DNA analysis of the species in Brazil. J Med Entomol 1996; 33(5): 839843. http://dx.doi.org/10.1093/jmedent/33.5.839. PMid:8840693.

Azeredo-Espin AM. Análise cariotípica, morfométrica e de compatibilidade sexual, em linhagens brasileiras de Cochliomyia hominivorax (Diptera: Calliphoridae) [tese]. Campinas: Universidade de Campinas; 1987.

Azevedo RR, Krüger RF. The influence of temperature and humidity on abundance and richness of Calliphoridae (Diptera). Iheringia Ser Zool 2013; 103(2): 145-152. http://dx.doi.org/10.1590/S0073-47212013000200010.

Azevedo WT, Figueiredo AL, Carvalho RP, Lemos GA, Silva PF, Miranda TA, et al. Record of the first cases of human myiasis by Lucilia cuprina (Diptera: Calliphoridae), Rio de Janeiro, Brazil. J Med Entomol 2015; 52(6): 1368-1373. http://dx.doi.org/10.1093/jme/tjv130. PMid:26336269.

Baptista MA. Images in clinical medicine. Nasal myiasis. N Engl J Med 2015; 372(12): e17. http://dx.doi.org/10.1056/NEJMicm1403473. PMid:25785986.

Barbosa LS, Cunha AM, Couri MS, Maia VC. Muscidae, Sarcophagidae, Calliphoridae e Mesembrinellidae (Diptera) da Estação Biológica de Santa Lúcia (Santa Teresa, Espírito Santo, Brasil). Bol Mus Biol Mello Leitão 2014; 33: 131-140.

Barbosa TS, Salvitti Sá Rocha RA, Guirado CG, Rocha FJ, Duarte Gavião MB. Oral infection by Diptera larvae in children: a case report. Int J Dermatol 2008; 47(7): 696-699. http://dx.doi.org/10.1111/j.13654632.2008.03725.x. PMid:18613876.

Barrientos Pontes J, Severo JEV, Garcia EFC, Colares R, Kohek Jr I, Reverbel MS. Projeto demonstrativo de controle e possível erradicação da mosca da bicheira. Hora Vet 2009; 29(171): 28-30.

Barros ATM, Ravaglia E, Aquino WS, Passos WM, Leite LTB. Eficácia de Endectocidas em Infestaçōes Naturais por Cochliomyia hominivorax (MoscaVarejeira) em Bezerros no Pantanal. Brasília: EMBRAPA; 2010a. pp. 1-4. (Circular Técnica EMBRAPA; 90) [cited 2018 Jan 12]. Available from: https://www.embrapa.br/en/busca-de-publicacoes/-/publicacao/862105/ eficacia-de-endectocidas-em-infestacoes-naturais-por-cochliomyiahominivorax-mosca-varejeira-em-bezerros-no-pantanal

Barros ATM, Ravaglia E, Aquino WS, Passos WM, Leite LTB. Avaliação de Extratos Vegetais na Prevenção e tratamento de Miíases Umbilicais em Bezerros no Pantanal. Brasília: EMBRAPA; 2010b. pp. 1-4. (Circular Técnica EMBRAPA; 89) [cited 2018 Jan 12]. Available from: https:// www.embrapa.br/en/busca-de-publicacoes/-/publicacao/862079/ avaliacao-de-extratos-vegetais-na-prevencao-e-tratamento-de-miiasesumbilicais-em-bezerros-no-pantanal

Batista-da-Silva JA, Abádio HC, Queiroz MMC. Miíase humana por Dermatobia hominis (Linneaus Jr.) (Diptera, Cuterebridae) e Cochliomyia hominivorax (Coquerel) (Diptera, Calliphoridae) em Sucessão Parasitaria. EntomoBrasilis 2009; 2(2): 61-63. http://dx.doi.org/10.12741/ebrasilis. v2i2.45.

Batista-da-Silva JA, Moya-Borja GE, Queiroz MMC. A severe case of cutaneous myiasis in Sao Goncalo, Brazil, and a simple technique to extract New World screw-worm Cochliomyia hominivorax (Coquerel) (Diptera: calliphoridae). Neotrop Entomol 2012; 41(4): 341-342. http:// dx.doi.org/10.1007/s13744-012-0038-8. PMid:23950071.

Batista-da-Silva JA, Moya-Borja GE, Queiroz MMC. Factors of susceptibility of human myiasis caused by the New World screw-worm, Cochliomyia 
hominivorax in São Gonçalo, Rio de Janeiro, Brazil. J Insect Sci 2011a; 11(1): 14. http://dx.doi.org/10.1673/031.011.0114. PMid:21526934.

Batista-da-Silva JA, Moya-Borja GE, Queiroz MMC. Miíases Humanas Causadas por Larvas de Cochliomyia hominivorax (Coquerel) (Diptera: Calliphoridae) em São Gonçalo, RJ, Brasil: Uma Abordagem SócioEconômica. EntomoBrasilis 2011b; 4(3): 144-146. http://dx.doi. org/10.12741/ebrasilis.v4i3.141.

Batista-da-Silva JA, Moya-Borja GE, Queiroz MMC. Patient with tracheostomy parasitized in hospital by larvae of the screwworm, Cochliomyia hominivorax. J Insect Sci 2011c; 11(163): 1-7. http://dx.doi. org/10.1673/031.011.16301. PMid:22243525.

Batista-da-Silva JA. Efeito da poluição causada por óleo mineral sobre a comunidade de Calliphoridae (Diptera, Oestroidea) em manguezal. Entomotrópica 2015; 30(5): 43-48.

Bergamo LW, Fresia P, Azeredo-Espin AM. Incongruent nuclear and mitochondrial genetic structure of new world screwworm fly populations due to positive selection of mutations associated with dimethyl- and diethyl-organophosphates resistance. PLoS One 2015; 10(6): e0128441. http://dx.doi.org/10.1371/journal.pone.0128441. PMid:26030866.

Bernaschina LMT. Levantamento de fauna diptera de interesse forense em carcaça de suino em ambiente de restinga arbórea em Florianópolis, Santa Catarina [monografia]. Florianópolis: Universidade Federal de Santa Catarina; 2016.

Bezerra ADS, Ahid SMM, Vieira LS, Soares HS. Ectoparasitos em caprinos e ovinos no município de Mossoró, Rio Grande do Norte. Cienc Anim Bras 2010; 11(1): 110-116.

Bianchin I, Corrêa ES, Gomes A, Honer MR, Curvo JE. Uso de ivermectin na prevenção das miíases em bezerros, de corte criados extensivamente. Brasília: EMBRAPA; 1991. pp. 1-2. (Comunicado técnico EMBRAPA Gado de Corte; 41) [cited 2018 Jan 12]. Available from: https://www. embrapa.br/en/busca-de-publicacoes/-/publicacao/319606/uso-deivermectin-na-prevencao-de-miiases-umbilicais-em-bezerros-de-cortecriados-extensivamente

Bianchin I, Côrrea ES, Honer MR, Gomes A, Curvo JE. Uso de ivermectin aplicado por via subcutânea na prevenção das miíases umbilicais em bezerros de corte criados extensivamente. Rev Bras Parasitol Vet 1992; 1(2): 121-124.

Bleyer J. Tratado de Myiasis: Ensaio de um estudo clínico sobre o papel das moscas na pathologia humana. Curitiba: Livraria Economica; 1905.98 p.

Braga LBF, Thompson NR, Gadelha BQ, Veloso ARA, Hoerlle MO, Coelho VMA, et al. Miíase associada a erisipela bolhosa. Rev Patol Trop 2011; 40(3): 271-276.

Brandão e Menezes LMS. Bicheiro das fossas nazaes [tese]. Rio de Janeiro: Faculdade de Medicina do Rio de Janeiro; 1875.

Brito DRB, Santos ACG, Guerra RMSNC. Ectoparasitos em rebanhos de caprinos e ovinos na microrregião do Alto mearim e Grajaú, estado do Maranhão. Rev Bras Parasitol Vet 2005; 14(2): 59-63. PMid:16153346.

Calderon P, Rojas C, Apt W, Castillo D. Miasis cutánea por Cochliomyia hominivorax asociada a dermatitis seborreica. Rev Med Chil 2017; 145(2): 250-254. http://dx.doi.org/10.4067/S0034-98872017000200013. PMid:28453592.

Cansi ER, Bonorino R, Ataide HS, Pujol-Luz JR. Myiasis by Screw Worm Cochliomyia hominivorax (Coquerel) (Diptera: Calliphoridae) in a Wild Maned Wolf Chrysocyon brachyurus (Mammalia: Canidae), in Brasilia, Brazil. Neotrop Entomol 2011; 40(1): 150-151. http://dx.doi. org/10.1590/S1519-566X2011000100025. PMid:21437499.
Cansi ER, Bonorino R. Miíase por Lucilia eximia (Diptera: Calliphoridae) em Didelphis albiventris (Mammalia: Didelphidae) no Brasil Central. EntomoBrasilis 2011; 4(3): 150-151. http://dx.doi.org/10.12741/ ebrasilis.v4i3.160

Cansi ER, Demo C. Ocorrência de miíases em animais de companhia no Distrito Federal, Brasil. Acta Sci Vet 2011; 39(3): 982.

Caproni L Jr, Umehara O, Gonçalves LCB, Moro E. Persistent efficacy of doramectin and ivermectin in the prevention of natural Cochliomyia hominivorax infestations in cattle castrated 10 days after treatment. Rev Bras Parasitol Vet 1998; 7(1): 57-61.

Cardoso GA, Marinho MA, Monfardini RD, Espin AM, Torres TT. Evolution of genes involved in feeding preference and metabolic processes in Calliphoridae (Diptera: calyptratae). PeerJ 2016; 4: e2598. http:// dx.doi.org/10.7717/peerj.2598. PMid:27812410.

Cardoso GA, Matiolli CC, Azeredo-Espin AM, Torres TT. Selection and validation of reference genes for functional studies in the Calliphoridae family. J Insect Sci 2014; 14(1): 2. http://dx.doi.org/10.1093/jis/14.1.2. PMid:25373149.

Carmo PMS, Vargas AC, Rissi DR, Oliveira-Filho JC, Pierezan F, Lucena $\mathrm{RB}$, et al. Surto de ceratoconjuntivite infecciosa bovina e hemoncose causando mortalidade em bezerros. Pesq Vet Bras 2011; 31(5): 374-378. http://dx.doi.org/10.1590/S0100-736X2011000500002.

Carvalho RA, Azeredo-Espin AM, Torres TT. Deep sequencing of New World screw-worm transcripts to discover genes involved in insecticide resistance. BMC Genomics 2010; 11(1): 695. http://dx.doi. org/10.1186/1471-2164-11-695. PMid:21143848.

Carvalho RA, Torres TT, Paniago MG, Azeredo-Espin AM. Molecular characterization of esterase E3 gene associated with organophosphorus insecticide resistance in the New World screwworm fly, Cochliomyia hominivorax. Med Vet Entomol 2009; 23(Suppl. 1): 86-91. http://dx.doi. org/10.1111/j.1365-2915.2008.00788.x. PMid:19335834.

Carvalho RW, Santos TS, Antunes AA, Laureano JR Fo, Anjos ED, Catunda RB. Oral and maxillofacial myiasis associated with epidermoid carcinoma: a case report. J Oral Sci 2008; 50(1): 103-105. http://dx.doi. org/10.2334/josnusd.50.103. PMid:18403893.

Cavalcante ANP, Dal-Bó D, Creão-Duarte AJ, Farias RCAP. Espécies de Calliphoridae (Diptera) associadas a carcaças de Sus scrofa Linnaeus, 1758 em área de restinga na Paraíba, Brasil, e espécies de importância forense para a estimativa do Intervalo Pós-Morte (IPM). Entomotrópica 2015; 30(15): 150-159.

Chicarelli M, Daniel AN, Santoro MA, Teodoro U. Miíase humana bucal por Cochliomyia hominivorax (Coquerel, 1858) em Nova Esperança, estado do Paraná, Brasil. Rev Fac Odontol - UPF 2002; 7(2): 39-41. https://doi. org/10.5335/rfo.v7i2.1217

Concha C, Palavesam A, Guerrero FD, Sagel A, Li F, Osborne JA, et al. A transgenic male-only strain of the New World screwworm for an improved control program using the sterile insect technique. BMC Biol 2016; 14(1): 72. http://dx.doi.org/10.1186/s12915-016-0296-8. PMid:27576512.

Corrêa EC, Koller WW, Barros ATM. Chrysomya (Diptera: Calliphoridae) relative abundance and species seasonality in the Pantanal, State of Mato Grosso do Sul, Brazil. Rev Bras Parasitol Vet 2010; 19(2): 85-88. http:// dx.doi.org/10.4322/rbpv.01902003. PMid:20624343.

Correia TR, Scott FB, Verocai GG, Souza CP, Fernandes JI, Melo $\mathrm{RM}$, et al. Larvicidal efficacy of nitenpyram on the treatment of myiasis caused by Cochliomyia hominivorax (Diptera: Calliphoridae) in dogs. 
Vet Parasitol 2010; 173(1-2): 169-172. http://dx.doi.org/10.1016/j. vetpar.2010.06.019. PMid:20638181.

Costa CAF, Vieira LS. Ectoparasitos permanentes de caprinos e ovinos em Sobral, CE. Pesqui Agropecu Bras 1984; 19(5): 639-646.

Costa FS, Bellotti A, Farah GJ, Camarini ET. Hipertratamento de miíase decorrente de trauma facial complexo. Rev Cir Traumatol Buco-MaxiloFac 2012; 12(3): 17-24.

Couri MS, Lamas CJE, Aires CCC, Mello-Patiu CA, Maia VC, Pamplona DM, et al. Diptera da Serra do Navio (Amapá, Brasil): Asilidae, Bombyliidae, Calliphoridae, Micropezidae, Muscidae, Sarcophagidae, Stratiomyiidae, Syrphidae, Tabanidae e Tachinidae. Rev Bras Zoociênc 2000; 2(1-2): 91-101.

Cramer-Ribeiro BC, Sanavria A, Monteiro HHM, Oliveira MQ, Souza FS. Inquiry of cases of myiasis by Cochliomyia hominivorax in dogs (Canis familiaris) of the Northern and Western zones of Rio de Janeiro city in 2000. Braz J Vet Res Anim Sci 2003; 40(1): 13-20. http://dx.doi. org/10.1590/S1413-95962003000100001.

Cramer-Ribeiro BC, Sanavria A, Oliveira MQ, Souza FS, Rocco FS, Cardoso PG. Inquérito sobre os casos de miíase por Cochliomyia hominivorax em cáes da zona sul do município do Rio de Janeiro no ano 2000. Braz J Vet Res Anim Sci 2002a; 39(4): 171-175. http://dx.doi.org/10.1590/ S1413-95962002000400002.

Cramer-Ribeiro BC, Sanavria A, Oliveira MQ, Souza FS, Rocco FS, Cardoso PG. Inquérito sobre os casos de miíase por Cochliomyia hominivorax em gatos das zonas norte, sul e oeste e do centro do município do Rio de Janeiro no ano 2000. Braz J Vet Res Anim Sci 2002b; 39(4): 165-170. http://dx.doi.org/10.1590/S1413-95962002000400001.

D’Almeida JM, Fraga MB. Efeito de diferentes iscas na atração de califorídeos (Diptera) no campus do Valonguinho, Universidade Federal Fluminense, Niterói, RJ, Brasil. Rev Bras Parasitol Vet 2007; 16(4): 199-204. http:// dx.doi.org/10.1590/S1984-29612007000400004. PMid:18373895.

D’Almeida JM. Sinantropia em dipteros caliptratos na área metropolitana do Rio de Janeiro [tese]. Rio de Janeiro: Universidade Federal Rural do Rio de Janeiro; 1983.

Deleito CSR, Moya-Borja GE. Nim (Azadirachta indica): uma alternativa no controle de moscas na pecuária. Pesq Vet Bras 2008; 28(6): 293-298. http://dx.doi.org/10.1590/S0100-736X2008000600006.

Duarte ER, Rocha FT, Teixeira LM, Silva RB, Nogueira FA, Silva $\mathrm{NO}$, et al. Ocorrência e tratamento de miíases cutâneas em ovinos criados em condições semiáridas no norte de Minas Gerais. Pesq Vet Bras 2012; 32(6): 490-494. http://dx.doi.org/10.1590/S0100-736X2012000600004.

Eizemberg R, Sabagh LT, Mello RS. First record of myiasis in Aplastodiscus arildae (Anura: Hylidae) by Notochaeta bufonivora (Diptera: Sarcophagidae) in the Neotropical area. Parasitol Res 2008; 102(2): 329-331. http:// dx.doi.org/10.1007/s00436-007-0767-5. PMid:17938961.

Esposito MC, Sousa JRP, Carvalho-Filho FS. Diversidade de Calliphoridae (Insecta: Diptera) na base de extração petrolífera da bacia do Rio Urucu, na Amazônia brasileira. Acta Amaz 2010; 40(3): 579-584. http://dx.doi. org/10.1590/S0044-59672010000300018.

Faria LS, Paseto ML, Couri MS, Mello-Patiu CA, Mendes J. Insects Associated with Pig Carrion in Two Environments of the Brazilian Savanna. Neotrop Entomol 2018; 47(2): 181-198. http://dx.doi.org/10.1007/ s13744-017-0518-y. PMid:28390027.

Fernandes LF, Pimenta FC, Fernandes FF. First report of human myiasis in Goiás state, Brazil: frequency of different types of myiasis, their various etiological agents, and associated factors. J Parasitol 2009; 95(1): 32-38. http://dx.doi.org/10.1645/GE-1103.1. PMid:18576696.

Ferraz AC, Almeida VRG, Jesus DM, Rotatori GN, Nunes R, Proenca B, et al. Epidemiological Study of Myiases in the Hospital do Andaraí, Rio de Janeiro, Including Reference to an exotic etiological Agent. Neotrop Entomol 2011; 40(3): 393-397. http://dx.doi.org/10.1590/ S1519-566X2011000300014. PMid:21710036.

Ferraz AC, Gadelha BQ, Aguiar-Coelho VM. Influência climática e antrópica na abundância e riqueza de Calliphoridae (Diptera) em fragmento florestal da Reserva Biológica do Tinguá, RJ. Neotrop Entomol 2010a; 39(4): 476-485. http://dx.doi.org/10.1590/S1519-566X2010000400004. PMid:20877981.

Ferraz AC, Gadelha BQ, Queiroz MM, Moya-Borja GE, Aguiar-Coelho VM. Effects of forest fragmentation on dipterofauna (Calliphoridae) at the Reserva Biológica do Tinguá, Nova Iguacu, RJ. Braz J Biol 2010b; 70(1): 55-63. http://dx.doi.org/10.1590/S1519-69842010000100009. PMid:20231960

Ferraz AC, Nunes R, Gadelha BQ, Nascimento BP, Barros PREM, Coelho VMA, et al. Raro caso de miíases por Cochliomyia hominivorax (Diptera: Calliphoridae) e Dermatobia hominis (Diptera: Oestridae) em paciente humano. Arq Ciênc Saúde 2008; 15(3): 142-144.

Fighera RA. Causas de morte e razóes para eutanásia em cães [tese]. Santa Maria: Universidade Federal de Santa Maria; 2008.

Figueirêdo CAS Jr. Diversidade genética de dípteros Calliphoridae de importância forense [tese]. Recife: Universidade Federal de Pernambuco; 2015.

Figueiredo MA, Santos ACG, Guerra RMSNC. Ectoparasitos de animais silvestres no Maranhão. Pesq Vet Bras 2010; 30(11): 988-990. http:// dx.doi.org/10.1590/S0100-736X2010001100013.

Figueiredo RR, Azevedo AA, Ávila Kós AO, Tomita S. Nasal foreign bodies: description of types and complications in 420 cases. Rev Bras Otorrinolaringol 2006; 72(1): 18-23. http://dx.doi.org/10.1590/S003472992006000100004. PMid:16917548.

Figueiredo RR, Dorf S, Couri MS, Azevedo AA, Mossumez F. Corpos estranhos animados em otorrinolaringologia. Rev Bras Otorrinolaringol 2002; 68(5): 722-728. http://dx.doi.org/10.1590/S0034-72992002000500019.

Franz I, Couri MS. A new host record for Philornis (Diptera, Muscidae). Rev Bras Entomol 2008; 52(4): 669-670. http://dx.doi.org/10.1590/ S0085-56262008000400020.

Fresia P, Azeredo-Espin AM, Lyra ML. The phylogeographic history of the new world screwworm fly, inferred by approximate bayesian computation analysis. PLoS One 2013; 8(10): e76168. http://dx.doi. org/10.1371/journal.pone.0076168. PMid:24098436.

Fresia P, Lyra ML, Coronado A, Azeredo-Espin AM. Genetic structure and demographic history of new world screwworm across its current geographic range. J Med Entomol 2011; 48(2): 280-290. http://dx.doi. org/10.1603/ME10153. PMid:21485363.

Fresia P, Silver M, Mastrangelo T, Azeredo-Espin AM, Lyra ML. Applying spatial analysis of genetic and environmental data to predict connection corridors to the New World screwworm populations in South America. Acta Trop 2014; 138(Suppl.): S34-S41. http://dx.doi.org/10.1016/j. actatropica.2014.04.003. PMid:24742908.

Fresia P. Análise filogeográfica da mosca da bicheira, Cochliomyia hominivorax [tese]. Campinas: Universidade de Campinas; 2011. 
Gadelha BQ, Ribeiro AC, Aguiar VM, Mello-Patiu CA. Edge effects on the blowfly fauna (Diptera, Calliphoridae) of the Tijuca National Park, Rio de Janeiro, Brazil. Braz J Biol 2015; 75(4): 999-1007. http://dx.doi. org/10.1590/1519-6984.05614. PMid:26675918.

Garcia-Zapata MT, Souza ESS Jr, Fernandes FF, Santos SFO. Human pseudomyiasis caused by Eristalis tenax (Linnaeus) (Diptera: Syrphidae) in Goiás. Rev Soc Bras Med Trop 2005; 38(2): 185-187. http://dx.doi. org/10.1590/S0037-86822005000200012. PMid:15821797.

Gealh WC, Ferreira GM, Farah GJ, Teodoro U, Camarini ET. Treatment of oral myiasis caused by Cochliomyia hominivorax: two cases treated with ivermectin. Br J Oral Maxillofac Surg 2009; 47(1): 23-26. http://dx.doi. org/10.1016/j.bjoms.2008.04.009. PMid:18514983.

Gennari SM, Kasai N, Caproni L Jr, Umehara O, Gonçalves LC, Derozier C. Control of gastrointestinal nematodes and productivity responses of grazing cattle treated with a two dose program of doramectin or ivermectin. Rev Bras Parasitol Vet 2000; 9(1): 71-75.

Giglioti R, Guimarães S, Oliveira-Sequeira TC, David EB, Brito LG, Huacca MEF, et al. Proteolytic activity of excretory/secretory products of Cochliomyia hominivorax larvae (Diptera: calliphoridae). Pesq Vet Bras 2016; 36(8): 711-718. http://dx.doi.org/10.1590/S0100-736X2016000800006.

Gomes A, Koller WW, Honer MR, Silva RL. Flutuação populacional da mosca Cochliomyia hominivorax (Coquerel, 1858) (Diptera: Calliphoridae) capturada em armadilhas orientadas pelo vento (W.O.T), no município de Campo Grande, MS. Rev Bras Parasitol Vet 1998; 7(1): 41-45.

Gomes de Araújo RJ, Hanna LMO, Gomes L, Carvalho LHV. Cochliomyia homnivorax em estágio avançado na cavidade oral. RGO 2009; 57(2): 229-233.

Gomez RS, Perdigão PF, Pimenta FJ, Rios Leite AC, Tanos de Lacerda JC, Custódio AL No. Oral myiasis by screwworm Cochliomyia hominivorax. $\mathrm{Br}$ J Oral Maxillofac Surg 2003; 41(2): 115-116. http://dx.doi.org/10.1016/ S0266-4356(02)00302-9. PMid:12694705.

Gonçalves LC, Dias A, Espindola CB, Almeida FS. Inventário de Calliphoridae (Diptera) em manguezal e fragmento de Mata Atlântica na região de Barra de Guaratiba, Rio de Janeiro, Brasil. Rev Bras Biol 2011; 9(1): 50-55.

Grisi L, Leite RC, Martins JRS, Barros ATM, Andreotti R, Cançado $\mathrm{PH}$, et al. Reassessment of the potential economic impact of cattle parasites in Brazil. Rev Bras Parasitol Vet 2014; 23(2): 150-156. http:// dx.doi.org/10.1590/S1984-29612014042. PMid:25054492.

Guimarães JH, Papavero N. Myiasis in man and animals in the Neotropical region: Bibliographic Database. São Paulo: Plêiade/FAPESP. 1999.

Harterreiten-Souza ES, Pujol-Luz JR. Comparative morphology of the spermathecae of some species of Chrysomya Robineau-Desvoidy and Cochliomyia Townsend (Diptera, Calliphoridae). Rev Bras Entomol 2012; 56(1): 54-58. http://dx.doi.org/10.1590/S0085-56262012005000002.

Hall M, Wall R. Myiasis of humans and domestic animals. Adv Parasitol 1995; 35: 257-334. http://dx.doi.org/10.1016/S0065-308X(08)60073-1. PMid:7709854.

Holanda LF, Pereira BJ, Holanda CV, Oliveira JG. Cerebral myiasis. Neurology 2015; 84(4): 434-435. http://dx.doi.org/10.1212/ WNL.0000000000001185. PMid:25628432.

Horn SC, Antônio RS. Carrapato, Berne e Bicheira no Brasil. Brasília: Ministério da Agricultura; 1983. p. 1-160.
Instituto Brasileiro de Geografia e Estatistica - IBGE. Pesquisa pecuária municipal [online]. Rio de Janeiro: IBGE; 2018 [cited 2019 Jan 28]. Available from: https://www.ibge.gov.br

Jorge IF, de Santana LR, Silveira MA, Brunetta DM, Kaufman J, BarrosoDuarte F. Oro-nasal myiasis in a lymphoma patient. Br J Haematol 2016; 175(5): 757. http://dx.doi.org/10.1111/bjh.14319. PMid:27610951.

Junqueira AC, Lessinger AC, Azeredo-Espin AM. Methods for the recovery of mitochondrial DNA sequences from museum specimens of myiasis-causing flies. Med Vet Entomol 2002; 16(1): 39-45. http://dx.doi. org/10.1046/j.0269-283x.2002.00336.x. PMid:11963980.

Koller WW, Barros AT, Corrêa EC. Abundance and seasonality of Cochliomyia macellaria (Diptera: Calliphoridae) in Southern Pantanal, Brazil. Rev Bras Parasitol Vet 2011; 20(1): 27-30. http://dx.doi.org/10.1590/ S1984-29612011000100006. PMid:21439228.

Koller WW, Gomes A, Gomes PR, Umaki A, Santos STP, Carvalho CJB. Dipteros Calliphoridae em mata ciliar remanescente no interior de pastagem cultivada, em Campo Grande, MS, Brasil [online]. 2002 [cited 2018 Aug 24]. Available from: https://www.researchgate.net/publication/262141222_ Dipteros_Calliphoridae_em_mata_ciliar_remanescente_no_interior_de_ pastagem_cultivada_em_Campo_Grande_MS_Brasil

Kosmann C, Prestes AC, Tepedino KP, Franco AC, Pujol-Luz CVA, Pujol-Luz JR. Lista das espécies de Calliphoridae (Diptera, Oestroidea) do Estado do Mato Grosso do Sul, Brasil. Iheringia Ser Zool 2017; 107(Suppl suppl): e2017140. http://dx.doi.org/10.1590/1678-4766e2017140.

Kosmann C. Calliphoridae (Diptera): identificação, sinantropia e análise microbiológica [tese]. Brasília: Universidade de Brasília; 2013.

Kotze PG, Martins JF, Steckert JS, Scolaro BL, Rocha JG, Miranda EF, et al. Infestação por Miíase em prolapso retal: relato de caso e revisão de literatura. Rev Bras Coloproctol 2009; 29(3): 382-285. http://dx.doi. org/10.1590/S0101-98802009000300014.

Laureano-Filho JR, Bezerra TP, Lima FT, Campelo RI. Extensive oral lesion colonized with 601 myiasis larvae. Trop Doct 2011; 41(1): 61-62. http://dx.doi.org/10.1258/td.2010.100308. PMid:21109606.

Lessinger AC, Azeredo-Espin AM. Evolution and structural organisation of mitochondrial DNA control region of myiasis-causing flies. Med Vet Entomol 2000; 14(1): 71-80. http://dx.doi.org/10.1046/j.13652915.2000.00209.x. PMid:10759315.

Lessinger AC, Junqueira ACM, Lemos TA, Kemper EL, Silva FR, Vettore $\mathrm{AL}$, et al. The mitochondrial genome of the primary screwworm fly Cochliomyia hominivorax (Diptera: calliphoridae). Insect Mol Biol 2000, 9(5): 521-529. http://dx.doi.org/10.1046/j.1365-2583.2000.00215.x. PMid:11029671.

Lima WS, Malacco MA, Bordin EL, Oliveira EL. Evaluation of the prophylactic effect and curative efficacy of fipronil $1 \%$ pour on (Topline) on post-castration scrotal myiasis caused by Cochliomyia hominivorax in cattle. Vet Parasitol 2004; 125(3-4): 373-377. http://dx.doi.org/10.1016/j. vetpar.2004.08.001. PMid:15482893.

Lima-Júnior SM, Asprino L, Prado AP, Moreira RW, Moraes M. Oral myiasis caused by Cochliomyia hominivorax treated nonsurgically with nitrofurazone: report of 2 cases. Oral Surg Oral Med Oral Pathol Oral Radiol Endod 2010; 109(3): e70-e73. http://dx.doi.org/10.1016/j. tripleo.2009.11.014. PMid:20219589.

Litjens P, Lessinger AC, de Azeredo-Espin AM. Characterization of the screwworm flies Cochliomyia hominivorax and Cochliomyia macellaria by PCR-RFLP of mitochondrial DNA. Med Vet Entomol 2001; 15(2): 183-188. http://dx.doi.org/10.1046/j.1365-2915.2001.00289.x. PMid:11434552. 
Lopes AM, Carvalho RA, Azeredo-Espin AM. Glutamate-gated chloride channel subunit cDNA sequencing of Cochliomyia hominivorax (Diptera: Calliphoridae): cDNA variants and polymorphisms. Invert Neurosci 2014; 14(2): 137-146. http://dx.doi.org/10.1007/s10158-014-0172-6. PMid:24929666.

Lopes WDZ, Chiummo RM, Vettorato LF, Castro Rodrigues D, Sonada $\mathrm{RB}$. The effectiveness of a fixed-dose combination pour-on formulation of $1.25 \%$ fipronil and $2.5 \%$ fluazuron against economically important ectoparasites and associated pharmacokinetics in cattle. Parasitol Int 2017; 66(5): 627-634. http://dx.doi.org/10.1016/j.parint.2017.05.005. PMid:28527785.

Lopes WDZ, Teixeira WFP, Felippelli G, Cruz BC, Maciel WG, Matos LVS, et al. Ivermectina e abamectina em diferentes doses e vias de aplicação contra larvas de Cochliomyia hominivorax em bolsas escrotais de bovinos recém-castrados, provenientes da regiáo sudeste do Brasil. Cienc Rural 2013; 43(12): 2195-2201. http://dx.doi.org/10.1590/ S0103-84782013001200013.

Lopes-Costa PV, dos Santos AR, Pereira-Filho JD, da Silva BB. Myiasis in the uterine cavity of an elderly woman with a complete uterine prolapse. Trans R Soc Trop Med Hyg 2008; 102(10): 1058-1060. http://dx.doi. org/10.1016/j.trstmh.2008.04.004. PMid:18495189.

Loureiro JFM, Corrêa PAF, Averbach M, Rossini GF, Paccos JL, Cavalcante RTM, et al. Intestinal myiasis. Rev Assoc Med Bras 2010; 56(6): 638. http:// dx.doi.org/10.1590/S0104-42302010000600008. PMid:21271126.

Lucares DO, Bernardes F Fo, Vega H, Kac BK, Pereira MR, Nery JAC. Inguinal ulcerated sebaceous carcinoma: an unusual presentation. $A n$ Bras Dermatol 2013;88(6 Suppl.1): 48-51. http://dx.doi.org/10.1590/ abd1806-4841.20132019. PMid:24346878.

Luiz HL, Taira TL, Koller WW. New records of Muscidae (Diptera) in Campo Grande, MS, Brazil. Rev Bras Parasitol Vet 2012; 21(4): 412-414. http://dx.doi.org/10.1590/S1984-29612012000400012. PMid:23295822.

Lustosa ES, Carvalho MESD, Carneiro JR, Silva IG. Artrópodes parasitos dos animais domésticos do estado de Goiás. Rev Patol Trop 1983; 12(1): 1-4.

Luz HR, Antonini RD, Rodrigues MS, Nunes-Freitas AF, Mello RS. First record of Philornis glaucinis Dodge \& Aitken, 1968 (Diptera: Muscidae) in Thalurania glaucopis Gmelin, 1788 (Aves: Trochilidae). Biotemas 2010; 23(3): 227-229. http://dx.doi.org/10.5007/2175-7925.2010v23n3p227.

Luz HR, Berto BP, Ferreira I, Antonini RD, Nunes-Freitas AF, MoyaBorja GE. Occurrence of Philornis bella Couri in nestlings of Tyrannus melancholicus Vieillot (Tyranninae) in the municipal district of Seropédica, Rio de Janeiro. Biotemas 2011; 24(2): 69-72. http://dx.doi. org/10.5007/2175-7925.2011v24n3p69.

Luz HR, Ferreira I, Couri MS. Larvas de Philornis deceptiva Dodge \& Aitken (Diptera, Muscidae) no Sanhaçu-cinzento Thraupis sayaca (Linnaeus 1766) (Thraupidae) no município de Seropédica, Rio de Janeiro, Brasil. Biota Neotrop 2008; 8(2): 255-257. http://dx.doi.org/10.1590/S167606032008000200024

Lyra ML, Hatadani LM, Azeredo-Espin AM, Klaczko LB. Wing morphometry as a tool for correct identification of primary and secondary New World screwworm fly. Bull Entomol Res 2010; 100(1): 19-26. http:// dx.doi.org/10.1017/S0007485309006762. PMid:19302726.

Lyra ML, Klaczko LB, Azeredo-Espin AM. Complex patterns of genetic variability in populations of the New World screwworm fly revealed by mitochondrial DNA markers. Med Vet Entomol 2009; 23(Suppl 1): 32-42. http://dx.doi.org/10.1111/j.1365-2915.2008.00776.x. PMid:19335828.
Madeira NG, Silveira GAR, Pavan C. The ocurrence of primary myisis in cats caused by Phaenicia eximia (Diptera: calliphoridae). Mem Inst Oswaldo Cruz 1989; 84(Suppl 4): 341. http://dx.doi.org/10.1590/ S0074-02761989000800060.

Manfrim AM, Cury A, Demeneghi P, Jotz G, Roithmann R. Miíase Nasal: relato de caso e revisão da literatura. Arq Int Otorrinolaringol 2007; 11(1): 74-79.

Marotta CR, Scherer PO, Sanavria A. Miíase interna oro-nasal e cutânea por Cochliomyia hominivorax (Coquerel, 1858) em felino (Felis catus)Relato de caso. Rev Bras Med Vet 2011; 33(3): 137-141.

Marquez AT, Mattos MS, Nascimento SB. Miíases associadas com alguns fatores sócio-econômicos em cinco áreas urbanas do Estado do Rio de Janeiro. Rev Soc Bras Med Trop 2007; 4(2): 175-180. http://dx.doi. org/10.1590/S0037-86822007000200006. PMid:17568884.

Martinez CAR, Romani G, Priolli DG, Campos AA, Carneiro VPP, Dalbem CAG. Miíase Vulvar: relato de Caso. Rev Bras Ginecol Obstet 2003; 25(4): 291-295. http://dx.doi.org/10.1590/S0100-72032003000400011.

Martins CA, Freddo AL, Gomes FV, Santos ME, Araldi CA, Heitz C. Oral myiasis. J Craniofac Surg 2012; 23(2): e69-e71. http://dx.doi. org/10.1097/SCS.0b013e31824685f7. PMid:22446462.

Martins-Junior JC, Keim FS, Iarocrinski J. Oftalmomiíase pós-traumática: relato de caso e revisão de literatura. Rev Bras Oftalmol 2010; 69(4): 264268. http://dx.doi.org/10.1590/S0034-72802010000400011.

Mastrangelo T, Fresia P, Lyra ML, Rodrigues RA, Azeredo-Espin AM. Genetic diversity and population structure of the New World screwworm fly from the Amazon region of Brazil. Acta Trop 2014; 138(Suppl): S26-S33. http://dx.doi.org/10.1016/j.actatropica.2014.04.002. PMid:24731964.

Mello-Patiu CA, Luna-Dias C. Myiasis in the neotropical amphibian Hypsiboas beckeri (Anura: Hylidae) by a new species of Lepidodexia (Diptera: Sarcophagidae). J Parasitol 2010; 96(4): 685-688. http://dx.doi. org/10.1645/GE-2423.1. PMid:20486737.

Melo REVA, Vitor CMA, Silva MBL, Luna LA, Firmo ACB. Miíases no lábio superior: apresentação de caso clínico. Int J Dent 2003; 2(1): 221-226.

Mendes-de-Almeida F, Labarthe N, Guerrero J, Landau-Remy G, Rodrigues DP, Moya-Borja GE, et al. Cochliomyia hominivorax myiasis in a colony of stray cats (Felis catus Linnaeus, 1758) in Rio de Janeiro, RJ. Vet Parasitol 2007; 146(3-4): 376-378. http://dx.doi.org/10.1016/j. vetpar.2007.02.021. PMid:17379414.

Moretti TC, Thyssen PJ. Miíase primária em coelho doméstico causada por Lucilia eximia (Diptera: Calliphoridae) no Brasil: relato de caso. Arq Bras Med Vet Zootec 2006; 58(1): 28-30. http://dx.doi.org/10.1590/ S0102-09352006000100005.

Muniz RA, Coronado A, Anziani OS, Sanavria A, Moreno J, Errecalde $\mathrm{J}$, et al. Efficacy of injectable doramectin in the protection of castrated cattle against field infestations of Cochliomyia hominivorax. Vet Parasitol 1995; 58(4): 327-333. http://dx.doi.org/10.1016/0304-4017(94)00730-Z. PMid:8533272.

Name KP, Barros-Cordeiro KB, Filho G, Wolff M, Pujol-Luz JR, Báo SN. Morphological and cytochemical aspects of spermatozoa in the genus Cochliomyia (Diptera: calliphoridae). J Electron Microsc 2012; 61(6): 415-422. http://dx.doi.org/10.1093/jmicro/dfs061. PMid:22997238.

Nascimento EMF, Oliveira JB, Paes MJ, Lobo AP, Silva LA, Santos Júnior ER, et al. Miíases humanas por Cochliomyia hominivorax (Coquerel, 1858) (Diptera, Calliphoridae) em hospitais públicos na cidade do Recife, Pernambuco, Brasil. Entomol Vectores 2005; 12(1): 37-51. http://dx.doi. org/10.1590/S0328-03812005000100003. 
Novo-Neto JP, Dos Santos FS, Pontes AE, Ribeiro FS, Scannavino FL, Martins AT. Oral Myiasis Caused by Cochliomyia hominivorax in a Disabled Person. Case Rep Pathol 2015; 2015: 904658. http://dx.doi. org/10.1155/2015/904658. PMid:26266071.

Oliveira CMB. Biologia, Flutuação populacional e patologia da Cochliomyia hominivorax (Coquerel, 1858) (Diptera: Calliphoridae) [dissertação]. Seropédica: Universidade Federal Rural do Rio de Janeiro; 1980.

Oliveira DL, Soares TF, Vasconcelos SD. Effect of bait decomposition on the attractiveness to species of Diptera of veterinary and forensic importance in a rainforest fragment in Brazil. Parasitol Res 2016; 115(1): 449-455. http://dx.doi.org/10.1007/s00436-015-4811-6. PMid:26547564.

Oliveira JAGP, Machado MI, Oliveira MP. Miíase de língua: relato de um caso de infestação hospitalar. Rev Cir Traumatol Buco-Maxilo-Fac 2008; 8(4): 47-50.

Oliveira MT, Rosa AC, Azeredo-Espin AM, Lessinger AC. Improving access to the control region and tRNA gene clusters of dipteran mitochondrial DNA.J Med Entomol 2006; 43(3): 636-639. http://dx.doi.org/10.1093/ jmedent/43.3.636. PMid:16739428.

Oliveira PC, Moraes PA, Scott FB, Verocai GG, Correia TR, Fernandes JI. Efficacy of spinosad on the treatment of myiasis caused by Cochliomyia hominivorax (Diptera: Calliphoridae) in dogs. Vet Parasitol 2018; 258: 53-56. http://dx.doi.org/10.1016/j.vetpar.2018.06.006. PMid:30105978.

Oliveira-Costa J, Oliveira RG, Bastos CS. Diptera calliphoridae de importância forense no município do Rio de Janeiro. Rev Eletron Novo Enfoque 2013; 16(16): 41-52.

Paim F. Controle seletivo do Rhipicephalus (Boophilus) microplus (Canestrini, 1887), em bovinos criados em campo nativo, com uso de fipronil e avaliação de sua eficácia em Lages - SC [dissertação]. Florianópolis: Universidade do Estado de Santa Catarina; 2010.

Passos MR, Varella RQ, Tavares RR, Barreto NA, Santos CC, Pinheiro VM, et al. Vulvar myiasis during pregnancy. Infect Dis Obstet Gynecol 2002; 10(3): 153-158. http://dx.doi.org/10.1155/S1064744902000157. PMid:12625971.

Pasternak J, Joo SH, Ganc AJ, Durão MS Jr, Morsh RD, Pinto TH. Um caso de infestação de orofaringe por Cochliomyia hominovorax. Einstein 2007; 5(2): 170-172.

Pena SB. Freqüência de dermatopatias infecciosas, parasitárias e neoplásicas em cães na região de Garça, São Paulo - Brasil [dissertação]. Botucatu:Universidade Estadual Paulista; 2007.

Pereira de Sousa JR, Carvalho-Filho FS, Esposito MC. Distribution and Abundance of Necrophagous Flies (Diptera: Calliphoridae and Sarcophagidae) in Maranhão, Northeastern Brazil. J Insect Sci 2015; 15(1): 70. http://dx.doi.org/10.1093/jisesa/iev054. PMid:26078304.

Pereira de Sousa JR, Carvalho-Filho FS, Juen L, Esposito MC. Evaluating the Effects of Different Vegetation Types on Necrophagous Fly Communities (Diptera: Calliphoridae; Sarcophagidae): Implications for Conservation. PLoS One 2016; 11(10): e0164826. http://dx.doi.org/10.1371/journal. pone.0164826. PMid:27798664.

Pierce AW. Myiasis. In: Braud AI. Medical microbiology and infectious diseases. Philadelphia: W.B. Saunders Company. 1981. p. 1704-1710.

Pires MS. Miíases umbilicais em bezerros nelore recém-nascidos: predisposiçāo em dois cruzamentos raciais criados no sistema de manejo voisin no Rio de Janeiro e avaliação de medidas profiláticas em criação extensiva no Pantanal Sul-Mato-Grossense [dissertação]. Seropédica: Universidade Federal Rural do Rio de Janeiro; 2008.
Reck J, Marks FS, Rodrigues RO, Souza UA, Webster A, Leite RC, et al. Does Rhipicephalus microplus tick infestation increase the risk for myiasis caused by Cochliomyia hominivorax in cattle? Prev Vet Med 2014; 113(1): 59-62. http://dx.doi.org/10.1016/j.prevetmed.2013.10.006. PMid:24176137.

Reis EMB, Spadetto RM, Amorim SL, Barioni G, Berbari Neto F. Squamous cell carcinoma in ovines in the state of Acre. Rev Caatinga 2016; 29(1): 234-238. http://dx.doi.org/10.1590/1983-21252016v29n127rc.

Reis FS, Barros MC, Fraga EC, Penha TA, Teixeira WC, Santos ACG, et al. Ectoparasitos de pequenos mamíferos silvestres de áreas adjacentes ao rio Itapecuru e área de preservação ambiental do Inhamum, estado do Maranhão, Brasil. Rev Bras Parasitol Vet 2008;17(1 Suppl 1): 69-74. PMid:20059819.

Ribeiro AL, Almeida TE, Lopes JS, Castro JF, Pinheiro JJ. Oral myiasis: does an indication for surgical treatment still exist? Two case reports. Oral Surg Oral Med Oral Pathol Oral Radiol Endod 2012a; 114(3): e10-e4. http://dx.doi.org/10.1016/j.oooo.2011.09.003. PMid:22862986.

Ribeiro CA No, Monnazzi MS. Oral myiasis in a patient with neurological signs. Br J Oral Maxillofac Surg 2016; 54(10): 1146-1147. http://dx.doi. org/10.1016/j.bjoms.2016.04.018. PMid:27138230.

Ribeiro MTF, Sanglard-Oliveira CA, Naves MD, Ferreira EF, Vargas AMD, Abreu MHNG. Miíase bucal e doença de Alzheimer: relato de caso clínico. Rev Bras Geriatr Gerontol 2012b; 15(4): 805-811. http:// dx.doi.org/10.1590/S1809-98232012000400019.

Ribeiro FAQ, Pereira CSB, Alves AC, Marcon MA. Tratamento da miíase humana cavitária com ivermectina oral. Rev Bras Otorrinolaringol 2001; 67(6): 755-761. http://dx.doi.org/10.1590/S0034-72992001000600002.

Ribeiro MC, Pepato AO, Matos FP, Sverzut CE, Abrahão AA, Trivellato AE. Oral myiasis in an elderly patient. Gerodontology 2010; 29(2): e1136-e1139. http://dx.doi.org/10.1111/j.1741-2358.2010.00432.x. PMid:21029155.

Ribeiro PB, Brum JGW, Costa PPR, Saul I. Influência da temperatura na captura de califorídeos em armadilhas W.O.T. Cochliomyia hominovorax e C. macellaria (Diptera-Calliphoridae). Rev Bras Parasitol Vet 1993; 2(1): 53-54.

Ribeiro PB, Costa PRP, Zanata J, Falkoski MH. Viabilidade e longevidade de pré- puppas e puppas de Cochliomyia hominivorax (Coquerel, 1858), no ambiente de Pelotas, RS. Arq Fac Vet UFRGS 1997; 25(1): 81-84.

Rivera B, Aycardi ER. Epidemiological evaluation of external parasites in cattle from the Brazilian Cerrados and the Colombian Eastern Plains. Zentralbl Veterinärmed B 1985; 32(6): 417-424. http://dx.doi. org/10.1111/j.1439-0450.1985.tb01979.x. PMid:4050207.

Rocha EM, Yvanoff JL, Silva LM, Prado AP, Caldato R. Massive orbital myiasis infestation. Arch Ophthalmol 1999; 117(10): 1436-1437. PMid:10532464.

Rocha UF, Vaz Z. Miiase e perfuração do rumen de bezerros por larvas de Cochliomyia hominivorax (Coquerel, 1858). Significação econômica. Rev Fac Med Vet S Paulo 1950; 4(2): 281-288. http://dx.doi.org/10.11606/ issn.2318-5066.v4i2p281-286.

Rodrigues FT, Klemig LR, Cardozo MRP, Alves PC, Aguiar VM, Lessa CS. Myiasis associated with an invasive ductal carcinoma of the left breast: case study. Rev Inst Med Trop São Paulo 2017; 59(0): e35. http://dx.doi. org/10.1590/s1678-9946201759035. PMid:28591263.

Rodrigues-Guimarães R, Guimarães RR, Barros HM, Carvalho RW, Moya-Borja GE. Sinantropia da fauna de Califorídeos (Diptera, 
Calliphoridae) na Baixada Fluminense, Rio de Janeiro, Brasil. Rev Cienc Tecnol 2008; 8(1): 22-33.

Rodriguez MEL, Aoki L, Nicoletti AGB, Matayoshi S, Fernandes JBVD. Ivermectina no tratamento de miíase orbitária - Relato de caso. Arq Bras Oftalmol 2003; 66(4): 519-521. http://dx.doi.org/10.1590/ S0004-27492003000400023.

Rossi JL Jr, Guiao-Leite FL, Gioso MA, Falqueiro LM, Fecchio RS. Oral myiasis in a captive hippopotamus. J Vet Dent 2009; 26(3): 168-170. http://dx.doi.org/10.1177/089875640902600304. PMid:19950517.

Rossi-Schneider T, Cherubini K, Yurgel LS, Salum F, Figueiredo MA. Oral myiasis: a case report. J Oral Sci 2007; 49(1): 85-88. http://dx.doi. org/10.2334/josnusd.49.85. PMid:17429188.

Salinas BCD, Lima IS Jr. Development of a trap for collecting Cochliomyia hominivorax (diptera: caliphoridae) flies. Rev Agrogeoambiental 2017; 9(2): 85-93. http://dx.doi.org/10.18406/2316-1817v9n22017977.

Sanavria A, Prata MCA. Eficácia profilática do doramectin contra infestaçôes naturais por Cochliomyia hominivorax em ovinos pós-castração. Rev Bras Parasitol Vet 1996; 5(2): 113-117.

Santos JS, Andena SR. Diversidade de dipteros de interesse forense com ênfase na taxonomia de Calliphoridae (Diptera), em área urbana e rural de Feira de Santana, Bahia, Brasil. [online] 2017 [cited 2018 Aug 24]. Available from: http://periodicos.uefs.br/index.php/semic/article/view/2182

Saraiva VS, Amaro MH, Belfort R Jr, Burnier MNJ Jr. A case of anterior internal ophthalmomyiasis: case report. Arq Bras Oftalmol 2006; 69(5): 741-743. http://dx.doi.org/10.1590/S0004-27492006000500023. PMid: 17187146

Schmidt C, Cargnelutti JF, Martins M, Weiblen R, Flores EF. Vacina experimental produzida em cultivo celular confere proteçáo parcial contra o ectima contagioso em ovinos. Pesq Vet Bras 2012; 32(1): 11-16. http:// dx.doi.org/10.1590/S0100-736X2012000100003.

Sellera FP, Barbosa BS, Gargano RG, Benesi FJ, Pogliani FC. Terapia fotodinâmica no tratamento de ferida causada por miíase em vulva de caprino - relato de caso. Acta Vet Brasilica 2014; 8(1): 74-77.

Seppanen M, Virolainen-Julkunen A, Kakko I, Vilkamaa P, Meri S. Myiasis during adventure sports race. Emerg Infect Dis 2004; 10(1): 137-139. http://dx.doi.org/10.3201/eid1001.020825. PMid:15078610.

Serbino NMB, Silva IF, Araujo RAB. Ocorrência e distribuição de mosca varejeira (Diptera: Calliphoridae) nas regiôes urbana, rural e silvestre do município de Porto Velho - RO. Rev Elet InterTexto 2010; 2010: 38-51.

Shinohara EH, Martini MZ, Oliveira HG No, Takahashi A. Oral myiasis treated with ivermectin: case report. Braz Dent J 2004; 15(1): 79-81. http://dx.doi.org/10.1590/S0103-64402004000100015. PMid:15322651.

Sidone OJG, Haddad EA, Mena-Chalco JP. A ciência nas regiōes brasileiras: evolução da produção e das redes de colaboração científica. Transinformacao 2016; 28(1): 15-32. http://dx.doi.org/10.1590/231808892016002800002 .

Silva BB, Borges US, Pimentel IC. Human vaginal myiasis caused by Cochliomyia hominivorax. Int J Gynaecol Obstet 2005a; 89(2): 152-153. http://dx.doi.org/10.1016/j.ijgo.2004.12.046. PMid:15847884.

Silva BB, Vieira SC, Coelho EG, Machado V, Borges US, Silveira Filho MA. Genital myiasis in a woman with psychiatric disturbance. BJOG 2005b; 112(7): 1000-1001. http://dx.doi.org/10.1111/j.14710528.2005.00556.x. PMid:15958009.

Silva DJ, Vianna WO, Lomba F. Inseticidas no controle de larvas de mosca da espécie Cochliomyia hominivorax (Coquerel). Bol Ind Anim 1991; 48(1): 1-6.
Silva HC, Prette N, Lopes WD, Sakamoto CA, Buzzulini C, Dos Santos TR, et al. Endectocide activity of a pour-on formulation containing 1.5 per cent ivermectin +0.5 per cent abamectin in cattle. Vet Rec Open 2015; 2(1): e000072. http://dx.doi.org/10.1136/vetreco-2014-000072. PMid:26392893.

Silva HC. Parâmetros farmacocinéticos e atividade endectocida de uma nova formulação contendo avermectinas, via tópica (pour-on), em bovinos [tese]. Jaboticabal: Universidade Estadual Paulista; 2008.

Silva NM, Carvalho RA, Azeredo-Espin AM. Acetylcholinesterase cDNA sequencing and identification of mutations associated with organophosphate resistance in Cochliomyia hominivorax (Diptera: calliphoridae). Vet Parasitol 2011; 177(1-2): 190-195. http://dx.doi. org/10.1016/j.vetpar.2010.11.017. PMid:21159442.

Silva RJ, Prado AP, Rodrigues RR, Lopes CA, Godoy WA. Megaselia scalaris (Diptera: Phoridae) causing myiasis in Crotalus durissus terrificus (Serpentes: Viperidae) in Brazil. J Med Entomol 1999; 36(5): 630. http:// dx.doi.org/10.1093/jmedent/36.5.630. PMid:10534959.

Souza A. Contribuição ao estudo das miíases em oto-rino-laringologia [tese]. Porto Alegre: Universidade Federal do Rio Grande do Sul; 1939.

Souza CP, Verocai GG, Ramadinha RH. Myiasis caused by the New World screwworm fly Cochliomyia hominivorax (Diptera: Calliphoridae) in cats from Brazil: report of five cases. J Feline Med Surg 2010a; 12(2): 166-168. http://dx.doi.org/10.1016/j.jfms.2009.08.003. PMid:19796976.

Souza JR, Pires MS, Sanavria A. Influência do clima e da cobertura de solo na mortalidade de Cochliomyia hominivorax (Coquerel, 1858) (Diptera: Calliphoridae) e na atuação de seus inimigos naturais. Biosci J 2010b; 26(1): 136-146.

Souza FL Jr, Souza CWO, Hipolito M, Baldassi L, Martins ML. Cases of buccal myiasis in the bullfrog (Rana cates beiana Shaw, 1802), with larvae of Notochaeta sp. Aldrich, 1916 (Diptera: Sarcophagidae) in São Paulo, Brazil. Mem Inst Oswaldo Cruz. 1989; 84(Suppl 4): 517-518. http://dx.doi.org/10.1590/S0074-02761989000800091

Sousa JRP, Esposito MC, Carvalho-Filho FS. Composição, abundância e riqueza de Calliphoridae (Diptera) das matas e clareiras com diferentes coberturas vegetais da Base de Extração Petrolífera, bacia do Rio Urucu, Coari, Amazonas. Rev Bras Entomol 2010; 54(2): 270-276. http://dx.doi. org/10.1590/S0085-56262010000200010.

Souza MS, Pepinelli M, de Almeida EC, Ochoa-Quintero JM, Roque FO. Blow flies from forest fragments embedded in different land uses: implications for selecting indicators in forensic entomology. J Forensic Sci 2016; 61(1): 93-98. http://dx.doi.org/10.1111/1556-4029.12869. PMid:26251038.

Souza TM, Figheira RA, Schmidt C, Requia AH, Brum JS, Martins $\mathrm{TB}$, et al. Prevalência das dermatopatias não-tumorais em cáes do município de Santa Maria, Rio Grande do Sul (2005-2008). Pesq Vet Bras 2009; 29(2): 157-162. http://dx.doi.org/10.1590/S0100-736X2009000200013.

Spagnol C, Loretti AP, Oliveira EC, Oliveira RT, Driemeier D. Aspectos epidemiológicos e patológicos da endocardite bacteriana em cães: 54 casos (2000-2005). Acta Sci Vet 2006; 34(3): 255-260. http://dx.doi. org/10.22456/1679-9216.15376.

Taira TL, Oliveira AD, Nicácio J, Abot AR, Koller WW, Rodrigues SR. Ocorrência de moscas sinantropicas em borda de mata de galeria, no sistema Serra de Maracaju [online]. Brasília: EMBRAPA; 2011 [cited 2018 Aug 24]. Available from: https://www.embrapa.br/en/busca-de-publicacoes/-/ publicacao/914750/ocorrencia-de-moscas-sinantropicas-em-borda-demata-de-galeria-no-sistema-serra-de-maracaju 
Takahagi RU, Gonçalves FP, Madeira NG, Schellini SA. Oftalmomiíase externa causada por Cochliomyia hominivorax. Rev Bras Oftalmol 2007; 66(1): 58-62.

Tarso P, Pierre-Filho P, Minguini N, Pierre LM, Pierre AM. Use of ivermectin in the treatment of orbital myiasis caused by Cochliomyia hominivorax. Scand J Infect Dis 2004; 36(6-7): 503-505. http://dx.doi. org/10.1080/00365540410020136. PMid:15307583.

Taylor DB, Peterson RD 2nd, Moya-Borja GE. Population genetics and gene variation in screwworms (Diptera: Calliphoridae) from Brazil. Biochem Genet 1996; 34(1-2): 67-76. http://dx.doi.org/10.1007/BF02396241. PMid:8935994

Teixeira DG, Borges LMF, Mastrangelo TA, Monteiro VN. Caracterização bioquímica do produto de excreção/secreçáo de larvas de Cochliomyia hominivorax (Diptera: calliphoridae). Cienc Anim Bras 2016; 17(4): 581592. http://dx.doi.org/10.1590/1089-6891v17i437176.

Teixeira WFP, Cruz BC, Maciel WG, Felippelli G, Matos LVS, Costa AJ. Miíase cervical em humano provocada por larvas de Cochliomyia hominivorax no Estado de Minas Gerais, Brasil - Relato de caso. Ars Vet 2013; 29(4): 110. http://dx.doi.org/10.15361/2175-0106.2013v29n4p110.

Thyssen PJ, Nassu MP, Costella AM, Costella ML. Record of oral myiasis by Cochliomyia hominivorax (Diptera: Calliphoridae): case evidencing negligence in the treatment of incapable. Parasitol Res 2012; 111(2): $957-$ 959. http://dx.doi.org/10.1007/s00436-012-2856-3. PMid:22350677.

Vale DS, Cavalieri I, Araujo MM, Santos MB, Santos Canellas JV, Espinola LV, et al. Myiasis in palate by Cochliomyia hominivorax. J Craniofac Surg 2011; 22(6): e57-e59. http://dx.doi.org/10.1097/SCS.0b013e318231e1f3. PMid:22134326.
Valviesse VRGA, Ferraz AC, Proenca B, Werneck GRN, Aguiar VM, Lessa CS. Míiase com exposição de calota craniana causada pela associação de Cochliomyia hominivorax (Coquerel, 1858), Cochliomyia macellaria (Fabricius, 1775) e Chrysomya albiceps (Wiedemann, 1819), (Diptera: Calliphoridae) em um paciente atendido em Hospital Público, Rio de Janeiro. Entomotrópica 2014; 29(3): 191-196.

Vargas MEI, Azeredo-Espin AM. Genetic Variability in Mitochondrial DNA of the Screwworm, Cochliomyia hominivorax (Diptera: Calliphoridae), from Brazil. Biochem Genet 1995; 33(7-8): 237-256. http://dx.doi. org/10.1007/BF02401854. PMid:8595051.

Vaz Z, Carvalho GT. Sobre um tipo interessante de miíase dos bezerros e seu agente causal. Rev Fac Med Vet S Paulo 1938; 1(1): 43-48. http:// dx.doi.org/10.11606/issn.2318-5066.v1i1p43-48.

Vianna EES, Costa PRP, Fernandes AL, Ribeiro PB. Abundância e flutuação populacional das espécies de Chrysomya (Diptera, Calliphoridae) em Pelotas, Rio Grande do Sul, Brasil. Iheringia Ser Zool 2004; 94(3): 231-234. http://dx.doi.org/10.1590/S0073-47212004000300002.

Wyss JH. Screwworm eradication in the americas. Ann N Y Acad Sci 2000; 916(1): 186-193. http://dx.doi.org/10.1111/j.1749-6632.2000. tb05289.x. PMid:11193620.

Xavier FS. Lesões proliferativas em pênis e prepúcio eqüinos [dissertação]. Pelotas: Universidade Federal de Pelotas; 2010.

Yarzon RMGB. Cochliomyia hominivorax (COQUEREL, 1858): meio alternativo para produção de larvas e testes prospectivos [dissertação]. Campo Grande: Universidade Federal de Mato Grosso do Sul; 2005.

Zumpt F. Myiasis in man and animals in the Old World: a textbook for physicians. Butterworth: Veterinarians, and Zoologists; 1965. 